\title{
Biogeography of tenebrionid beetles (Coleoptera: Tenebrionidae) in the circum-Sicilian islands (Italy, Sicily): Multiple biogeographical patterns require multiple explanations
}

\author{
SiMONE FATTORINI \\ WET - Water Ecology Team, Department of Biotechnology and Biosciences, University of Milano Bicocca, Piazza della Scienza 2 , \\ 20126 Milano, Italy; e-mail: simone_fattorini@virgilio.it \\ Azorean Biodiversity Group, Departamento de Ciências Agrárias, Universidade dos Açores, Pico da Urze, \\ 9700-042 Angra do Heroísmo, Portugal
}

Key words. Biogeography, Coleoptera, Tenebrionidae, Mediterranean, Pleistocene, Sicily, species-area relationship

\begin{abstract}
The tenebrionid beetles on 25 circum-Sicilian islands were studied to determine the influence of island geographical and landscape features on three main intercorrelated biogeographical patterns: (1) species richness, studied using species-area and species environment relationships, (2) species assemblage composition, investigated using Canonical Correspondence Analysis (CCA), and (3) inter-site faunal similarity, investigated using Canonical Correlation Analysis (CANCOR) applied to multidimensional scaling of inter-island faunal dissimilarities. Species richness was mostly influenced by island area and landscape heterogeneity (expressed using various indices of diversity based on land cover categories). When species identities were considered in the CCA, no substantial effect of landscape was detected. Current island isolation did not have a strong influence on species richness, but has a distinct effect in determining species assortments on the remotest islands. Historical influences of Pleistocene landbridge connections were not detectable in species richness relationships using geographical variables in species richness analyses or in assemblage gradients in the CCA, but emerged distinctly from inter-island similarities in the CANCOR.
\end{abstract}

\section{INTRODUCTION}

Recently there have been advances in Mediterranean island biogeography in terms of the influence of geographical and ecological (environmental) factors on species richness (Foufopoulos \& Ives, 1999; Fattorini, 2002b, 2006b, 2007, 2009b, c; Hausdorf \& Hennig, 2005; Dapporto \& Dennis, 2008a, b), species composition (Dennis et al., 2008; Dapporto \& Dennis, 2009; Fattorini, 2011) and inter-island faunal similarities (Dennis et al., 2000; Fattorini, 2002a, 2006a, 2009a, 2010; Hausdorf \& Hennig, 2005; Dapporto \& Cini, 2007; Dapporto et al., 2007).

There is a large body of literature on the relationships between species richness and geographical and ecological factors, such as area, isolation, age and environmental diversity in the most disparate kinds of archipelagos (Whittaker et al., 2008). These studies typically use correlation analyses, multiple regressions, structural equations or similar techniques to relate species number to the variables of interest (Fattorini, 2002a, b, 2006a, 2007, 2009a, c; Hausdorf \& Hennig, 2005; Dapporto et al., 2007; Dapporto \& Cini, 2007; Dapporto \& Dennis, 2008a).

The importance of geographical and ecological factors in explaining inter-island faunal similarities has received less attention. Studies in this field typically correlate (using Mantel tests) matrices of biogeographical distances with matrices of geographical/environmental distances (see, for example, Hausdorf \& Hennig, 2005; Dapporto \& Cini, 2007; Fattorini, 2009a, c, 2010) or use a Canonical Correlation Analysis (CANCOR) of a number of dimen- sions summarizing the biogeographical positions of islands in multidimensional space (e.g. dimensions from Multidimensional Scaling) and values of geographical/ environmental variables (see Fattorini, 2006a).

Finally, there are few studies on how geographical and environmental factors may explain species composition on islands and the use of Canonical Correspondence Analysis (CCA) to correlate species distributions with island characteristics was only recently proposed (Fattorini, 2011). No study, however, has integrated these different approaches by simultaneously investigating these three aspects of variation on community structure.

In this paper, these three aspects of the fauna of tenebrionid beetles (Coleoptera: Tenebrionidae) on the islands surrounding Sicily, the largest Mediterranean island, were investigated simultaneously. Sicily is surrounded by a number of small islands, collectively known as the "circum-Sicilian" islands. Some of them form small archipelagos, while others are isolated, and their distance from Sicily varies considerably. The biogeography of the circum-Sicilian islands is particularly complex (e.g. Corti, 1973; Capula, 1994; Corti et al., 1998; Harris et al., 2009), because the islands vary greatly in terms of their geological origin (volcanic vs. sedimentary), paleogeography (some were connected to Sicily or Africa during Pleistocene glaciations, others remained isolated), distance to the main source of colonization (Sicily or Africa), area (Malta, the largest island, has an area of $245.7 \mathrm{~km}^{2}$, but most of the islands are smaller than 30 $\mathrm{km}^{2}$ ) and environmental conditions. Moreover, their loca- 
tion at the boundary between Europe and Africa makes their faunal composition a mosaic of European and African elements (Fattorini, 2010, 2011) with important conservation implications (Fattorini, 2008b).

Thanks to their low dispersal ability, tenebrionids are excellent biogeographical markers of historical processes (Fattorini, 2001b, 2008a, 2009a, c). They have been repeatedly used to investigate the biogeography of Mediterranean islands (e.g. Fattorini 2002a, 2006a, b, 2009a, c, 2010, 2011; Hausdorf \& Hennig, 2005). The distribution of tenebrionid beetles on the circum-Sicilian islands is well known, yet there is no comprehensive biogeographical study. In this paper, the tenebrionid beetles on the circum-Sicilian islands are used to explore how the same geographical and environmental factors influence species richness, species composition of communities and variation in the similarity of communities.

\section{MATERIAL AND METHODS}

\section{Study islands}

The circum-Sicilian islands (Fig. 1) can be grouped into four main archipelagos: the Aeolian Islands (volcanic), the Egadi Islands (sedimentary), the Pelagie Islands (both volcanic and sedimentary) and the Maltese Islands (sedimentary); the remaining two islands, Ustica and Pantelleria (both volcanic), are rather isolated. The Aeolian Islands are separated from Sicily by a sea channel of about $1000-2000 \mathrm{~m}$ depth and thus they have always remained apart from Sicily, even during Pleistocene falls in sea level. The sea between the islands (except between Vulcano and Lipari) is also very deep (about 400-1400 $\mathrm{m})$ and prevented Pleistocene inter-island connections. All the Egadi islands are calcareous and at least two islands, Favignana and Levanzo, were repeatedly connected to Sicily either in the Lower and Middle Pleistocene (Calabrian and Ionian stages) between 1.8 million and 126,000 years ago or in the Upper Pleistocene (Tarantian stage) during the Würm glaciation about 18,000 years ago. The island of Ustica is separated from Sicily by a deep and wide sea channel and has always remained apart from Sicily, even during Pleistocene falls in sea level. Lampedusa and Lampione are an emerged portion of the African continental shelf, and were connected to North Africa during the Würm glaciation. Pantelleria and Linosa were not connected to mainland areas (Sicily or North Africa). Finally, the Maltese Islands were connected to Sicily and probably to North Africa during the Pleistocene, but their separation from Africa occurred long before that from Sicily. For detailed information on these islands see Corti (1973), Mazzola et al. (2001) and The Maltese Islands Multimedia Encyclopedia (2011).

\section{Measurements of geographical and environmental variables}

The geographical parameters are summarized in Table 1 . Both island area and isolation are important factors regulating species occurrences on islands (Whittaker, 1998). As measures of island isolation, I considered here both island distance to Sicily or North Africa (both considered as the closest "mainland" areas) and to the nearest island (Table 1); see Fattorini (2010) for details.

Sea level changed greatly during the Pleistocene, determining both inter-island and island-mainland connections. As a rule, falls in sea level connected areas above a depth of 200-150 m. It can be assumed that, during Pleistocene falls in sea level, lower depths permitted longer connections with wider land bridges between islands and/or to the mainland. Thus, to study the influence of paleogeography on species richness and composition, I
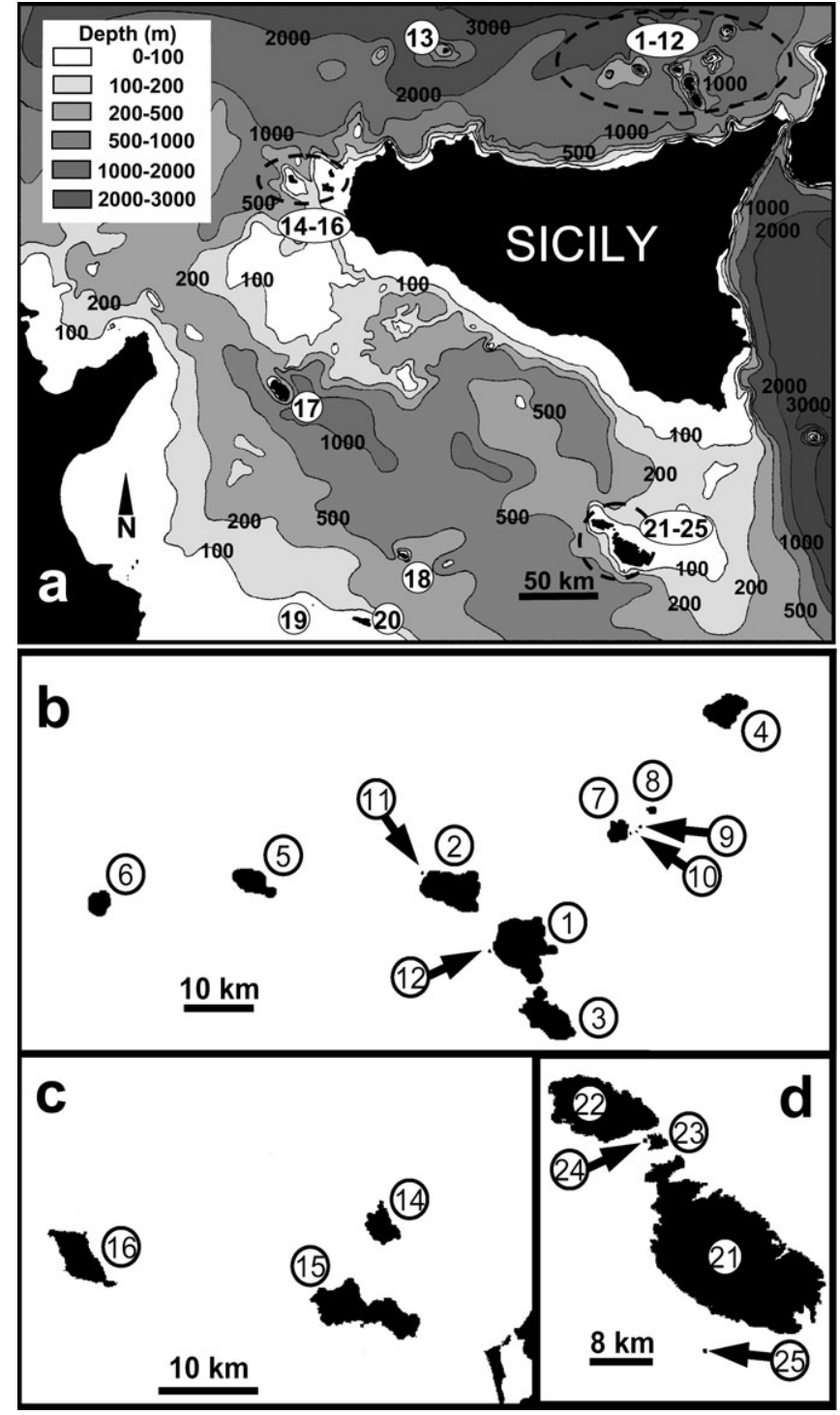

Fig. 1. Map of the study area with sea depths (a). Island positions within archipelagos are detailed for the Aeolian (b), Egadi (c) and Maltese Islands (d). Islands names are as follows: 1 Lipari, 2 - Salina, 3 - Vulcano, 4 - Stromboli, 5 - Filicudi, 6 Alicudi, 7 - Panarea, 8 - Basiluzzo, 9 - Lisca Bianca, 10 - Bottaro, 11 - Scoglio Faraglione, 12 - Pietra del Bagno, 13 Ustica, 14 - Levanzo, 15 - Favignana, 16 - Marettimo, 17 Pantelleria, 18 - Linosa, 19 - Lampione, 20 - Lampedusa, 21 Malta, 22 - Gozo, 23 - Comino, 24 - Cominotto, 25 - Filfla.

used sea depths among islands and between islands and the mainland (Crowell, 1986).

To characterize environmental conditions, I calculated the extent of island surface occupied by different land cover categories according to the European Corine Land Cover classification. Although somewhat crude, Corine land cover categories are extensively used to express species-environment relationships (e.g., Lobo \& Martín-Piera, 2002; Stefanescu et al., 2004; Maes et al., 2005). A total of 24 land cover categories were found on the circum-Sicilian islands. This is too many predictors compared to the small number of islands composing the archipelago. Moreover, some categories were represented by very small patches or can be easily combined into broader categories. Thus, I constructed the following main categories of landscape types (Table 2): Built up areas (including Continuous 
TABLE 1. Geographical variables for the circum-Sicilian islands. $S$ - number of species; $A$ - Area $\left(\mathrm{km}^{2}\right) ; D s-$ Distance to Sicily $(\mathrm{km}) ; D a$-Distance to North Africa (km); $D i$ - Distance to the nearest island (km); $S D s$ - Sea depth to Sicily (m below sea level); $S D a$ - Sea depth to Africa (m below sea level); $S D i$ - Sea depth to the nearest island (m below sea level). $X_{1}, X_{2}$ and $X_{3}$ are the three dimensions extracted by Non-metric Multidimensional Scaling from a matrix of inter-island faunal dissimilarity (Kulczinski 2 index).

\begin{tabular}{lccccccccccc}
\hline Island & $S$ & $A$ & $D s$ & $D a$ & $D i$ & $S D s$ & $S D a$ & $S D i$ & $X_{1}$ & $X_{2}$ & $X_{3}$ \\
\hline 1. Lipari & 32 & 37.29 & 28 & 370 & 1 & 780 & 1500 & 10 & -0.306 & -0.049 & 0.075 \\
2. Salina & 24 & 26.38 & 39 & 365 & 4 & 780 & 1500 & 366 & -0.392 & 0.169 & -0.178 \\
3. Vulcano & 22 & 20.87 & 21 & 375 & 1 & 780 & 1500 & 10 & -0.181 & 0.248 & 0.073 \\
4. Stromboli & 25 & 12.19 & 58 & 405 & 18 & 1200 & 1500 & 1281 & -0.255 & 0.326 & -0.330 \\
5.Filicudi & 15 & 9.49 & 46 & 345 & 15 & 1500 & 1500 & 1281 & -0.629 & -0.038 & 0.416 \\
6. Alicudi & 18 & 5.1 & 53 & 330 & 15 & 1500 & 1500 & 1281 & -0.562 & 0.040 & 0.220 \\
7. Panarea & 22 & 3.34 & 42 & 390 & 14 & 780 & 1500 & 600 & -0.582 & -0.033 & -0.010 \\
8. Basiluzzo & 3 & 0.29 & 43.5 & 394 & 3.5 & 780 & 1500 & 80 & -1.004 & 0.603 & 0.339 \\
9. Lisca Bianca & 4 & 0.0413 & 42 & 390 & 3 & 780 & 1500 & 50 & -0.917 & 0.290 & -0.152 \\
10. Bottaro & 7 & 0.0073 & 42 & 390 & 2.75 & 780 & 1500 & 50 & -0.831 & -0.032 & -0.102 \\
11. Scoglio Faraglione & 4 & 0.0049 & 39 & 365 & 0.27 & 780 & 1500 & 10 & -0.737 & -0.036 & -0.628 \\
12. Pietra del Bagno & 3 & 0.0021 & 28 & 370 & 0.45 & 780 & 1500 & 20 & -0.283 & -0.089 & -0.596 \\
13. Ustica & 26 & 8.6 & 53 & 255 & 100 & 1500 & 1500 & 1500 & -0.334 & -0.416 & 0.326 \\
14. Levanzo & 18 & 5.61 & 12 & 152 & 4 & 42 & 400 & 42 & -0.108 & -0.468 & 0.484 \\
15. Favignana & 28 & 19.7 & 8 & 140 & 4 & 42 & 400 & 42 & 0.001 & -0.410 & 0.326 \\
16. Marettimo & 16 & 12.06 & 35 & 130 & 15 & 145 & 400 & 145 & 0.314 & -0.322 & 1.046 \\
17. Pantelleria & 23 & 86 & 95 & 67 & 115 & 500 & 500 & 500 & 0.292 & -1.255 & 0.066 \\
18. Linosa & 19 & 5.34 & 162 & 163 & 40 & 500 & 400 & 400 & 0.247 & -1.021 & -0.675 \\
19. Lampione & 4 & 0.025 & 220 & 130 & 18 & 500 & 100 & 100 & 0.234 & 1.762 & -0.285 \\
20. Lampedusa & 28 & 20.2 & 195 & 120 & 18 & 500 & 100 & 400 & 0.646 & -0.527 & -0.879 \\
21. Malta & 43 & 246 & 93 & 292 & 6 & 200 & 500 & 100 & 0.871 & 0.018 & 0.144 \\
22. Gozo & 26 & 67 & 82 & 285 & 6 & 200 & 500 & 100 & 1.121 & 0.015 & 0.033 \\
23. Comino & 10 & 3.5 & 85 & 295 & 2 & 200 & 500 & 100 & 0.961 & 0.417 & -0.441 \\
24. Cominotto & 2 & 0.25 & 85 & 295 & 0.1 & 200 & 500 & 100 & 1.389 & 0.378 & -0.413 \\
25. Filfla & 3 & 0.06 & 100 & 292 & 5 & 200 & 500 & 100 & 1.047 & 0.432 & 1.141 \\
\hline & & & & & & & & & & &
\end{tabular}

urban fabric, Discontinuous urban fabric, Industrial or commercial units, Port areas, Airports, Mineral extraction sites, Dump Sites, Green urban areas, and Sports and Leisure facilities), Cultivation (including Vineyards, Non-irrigated arable land, Natural grassland, Annual crops associated with permanent crops, Complex cultivation patterns, and Land principally occupied by agriculture, with significant areas of natural vegetation), Coniferous forest, Broad-leaved and Mixed forests, Sclerophyllous vegetation, Bare rock and Sparsely vegetated areas, and Wet areas (including Salt marshes, Salines, and Water bodies). Even if these broad landscape units are coarse in comparison to the scale at which insects perceive small-scale environmental heterogeneity, they correspond well to distinct keystone structures (Tews et al., 2004) for tenebrionid species. In particular, each of the seven classes used here corresponded to different microclimate conditions, food resources, and soil characteristics, which are among the most important factors shaping tenebrionid communities in the Mediterranean (Fattorini, 2008b).

Geographical distances and land cover categories were obtained from the GIS of the Italian Ministry of the Environment and Protection of the Territory and Sea (2009) and from Malta Environment and Planning Authority (2009). Sea depths were obtained from bathymetric maps mainly from the Istituto Idrografico della Marina (1997).

\section{Biological data}

Presence/absence data of individual species on each island (Appendix 1) are based on extensive field surveys made by specialists with similar sampling efforts among islands; the faunal inventories are fairly complete. A total of 107 native taxa are known from these islands.
There are indications that various insular populations of tenebrionid beetles described as subspecies differ profoundly genetically (cf. Chatzimanolis et al., 2003; Ferrer, 2008). The current taxonomic dividing line between species and subspecies, as applied to the tenebrionids of the circum-Sicilian islands, is arguably arbitrary and the exclusion of subspecies could result in a significant underestimate of endemic island tenebrionid diversity. Thus, I considered both species and subspecies as "evolutionarily significant units" (Ryder, 1986) and included both categories in all analyses. The validity of the endemic subspecies Heliopathes avarus donatellae (Canzoneri, 1970) is disputed and the identity of the endemic species Opatrum melitense Küster, 1849 is uncertain. Both taxa have been provisionally considered as valid. On the basis of the original description, the differentiation of Heliopathes avarus dwejrensis Scupola \& Mifsud, 2001 from Gozo seems very subtle. The same is the case for Probaticus cossyrensis Sparacio, 2007, which was recently separated from Probaticus anthrax Seidlitz, 1896. All analyses were performed including and excluding these two taxa. Only results with all taxa included are presented, because exclusion of these two taxa produced virtually identical results.

Finally, cosmopolitan species strictly associated with human food, such as Palorus subdepressus (Wollaston, 1864), Gnatocerus cornutus (Fabricius, 1798), Alphitobius diaperinus (Panzer, 1796), Tenebrio spp. and Tribolium spp. were excluded from all analyses to reduce the risk of confounding natural patterns with effects of man. A list of 45 references used to compile presence/absence data is given in Appendix 1. 
TABLE 2. Extent $\left(\mathrm{km}^{2}\right)$ of land cover categories and values of environmental (landscape) heterogeneity indices. $N-$ number of land cover categories present on an island. Land cover categories: $B U$ - Built up areas; $C U$ - Cultivation; $C O$ - Coniferous forests; $B L$ - Broad-leaved and Mixed Forests; $S C$ - Sclerophyllous vegetation; $B R$ - Bare rock and sparsely vegetated areas; $W A$ - Wet areas. Landscape heterogeneity indices: $C$ - Simpson dominance index; $H$ - Shannon index; $e^{H} / N$ - Buzas and Gibson evenness; $J-$ Pielou equitability; $D_{\mathrm{Mg}}-$ Margalef richness index; $d$ - Berger-Parker dominance.

\begin{tabular}{|c|c|c|c|c|c|c|c|c|c|c|c|c|c|c|}
\hline \multirow{2}{*}{ Islands } & \multirow{2}{*}{$\Lambda$} & \multicolumn{7}{|c|}{ Landcover categories } & \multicolumn{6}{|c|}{ Heterogeneity indices } \\
\hline & & $B U$ & $C U$ & $\mathrm{CO}$ & $B L$ & $S C$ & $B R$ & $W A$ & $C$ & $H$ & $e^{H} / N$ & $J$ & $D_{M g}$ & $d$ \\
\hline 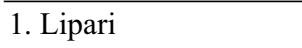 & 4 & 9.397 & 13.196 & 0.000 & 000 & 8.198 & 498 & 00 & 268 & 1.352 & 0.967 & .976 & .285 & 0.354 \\
\hline & 3 & 3.897 & 98 & 0.000 & 000 & .185 & 000 & & 566 & .774 & 0.723 & 0.705 & .197 & 0.727 \\
\hline 3. $\mathrm{Vu}$ & 5 & 3.598 & 5 & 0.000 & 4 & 05 & 67 & & 79 & 1.380 & 95 & 57 & 2 & 360 \\
\hline & 3 & 1.125 & 00 & 0.000 & 0.000 & 7.033 & 4.032 & & 451 & 0.903 & 0.823 & .822 & 0.213 & 0.577 \\
\hline 5.Fil & 3 & 0.000 & 98 & 0.000 & 00 & 6.693 & 799 & 00 & 549 & 0.783 & 0.729 & 712 & 0.218 & 0.705 \\
\hline 6. $\mathrm{Al}$ & 3 & 0.400 & 0.000 & 0.000 & 0.000 & 3.000 & 1.700 & 0.000 & 0.463 & 0.878 & 0.802 & 0.799 & 0.234 & 0.588 \\
\hline & $J$ & 0.786 & 0.000 & 0.000 & 0.000 & 1.866 & 0.688 & & 411 & 0.991 & 0.898 & 0.902 & & 0.559 \\
\hline 8.1 & 1 & 0.000 & 0.000 & 0.000 & 0.000 & 0.290 & 0.000 & 0.000 & 1.000 & 0.000 & 1.000 & 0.000 & 00 & 00 \\
\hline 9. $\mathrm{Li}$ & 1 & 0.000 & 0.000 & 0.000 & 0.000 & 0.000 & 0.000 & 0.041 & 1.015 & -0.007 & 0.993 & 0.000 & 0.000 & 1.000 \\
\hline 10. $\mathrm{B}$ & 1 & 0.000 & 0.000 & 0.000 & 0.000 & 0.000 & 0.000 & & 088 & -0.044 & 57 & 00 & 00 & 1.000 \\
\hline 11. $\mathrm{s}$ & 1 & 0.000 & 0.000 & 0.000 & 0.000 & 0.005 & 0.000 & 0.000 & 1.501 & -0.249 & 0.780 & 0.000 & 0.000 & 1.000 \\
\hline & 1 & 0.000 & 0.000 & 0.000 & 0.000 & 0.000 & 0.000 & 0.002 & 1.103 & -0.051 & 0.950 & 0.000 & 0.000 & 1.000 \\
\hline & 5 & & & & & & & & & & & & & \\
\hline & 2 & 0.000 & 06 & 0.000 & 0.000 & 4.604 & 0 & 0 . & 06 & 0.470 & 0.800 & 0.678 & 0.116 & 0.821 \\
\hline & 3 & 0.861 & 13.864 & 0.000 & .000 & 4.975 & 0.000 & 0.000 & 561 & 0.732 & 0.693 & 0.666 & 0.202 & 0.704 \\
\hline & 3 & 0.000 & & 0.000 & & 0.226 & & & & 0.528 & & 81 & 0.213 & 0.848 \\
\hline 17. Pantelle & 5 & 8.671 & 51.041 & 6.196 & 0.000 & 19.801 & 0.000 & 0.291 & 0.421 & 1.088 & 0.594 & 0.676 & 0.352 & 0.594 \\
\hline 18. Linosa & 3 & 0.854 & 17 & 0.000 & 0.000 & 69 & & & 32 & 56 & 67 & 0.871 & & 0.584 \\
\hline & 1 & 0.000 & 0.000 & 0.000 & 0.000 & 0.000 & & & 1.000 & 0.000 & 1.000 & 0.000 & 0.000 & 1.000 \\
\hline 20. La & 4 & 2.898 & 5.741 & 0.857 & 0.000 & 10.704 & 0.000 & 0.000 & 0.384 & 1.107 & 0.756 & 0.798 & 0.303 & 0.530 \\
\hline $21 . \mathrm{N}$ & 7 & 80.380 & 126.750 & 0.694 & 1.488 & 33.156 & 3.272 & & & 1.089 & 0.425 & 0.560 & 0.483 & 0.515 \\
\hline 22. Gozo & 4 & 29.458 & 27.761 & 0.000 & 0.000 & 9.562 & 0.219 & 0.000 & 0.385 & 1.023 & 0.695 & 0.738 & 0.270 & 0.440 \\
\hline & 1 & & & & & & & & & 0.000 & & 0.000 & & 1.000 \\
\hline & 1 & 0.000 & 0.000 & 0.000 & 0.000 & 0.250 & 0.000 & 0.000 & 1.000 & 0.000 & 1.000 & 0.000 & 0.000 & 1.000 \\
\hline 25. Filfla & 1 & 0.000 & 0.000 & 0.000 & 0.000 & 0.060 & 0.000 & 0.000 & 1.000 & 0.000 & 1.000 & 0.000 & 0.000 & 1.000 \\
\hline
\end{tabular}

\section{Data analysis}

Correlation of species richness with geographical and environmental variables

One of the most controversial issues in island biogeography is the importance of "habitat diversity" and area per se in determining species numbers (Whittaker, 1998; Fattorini, 2006a; Hortal et al., 2009). To express "habitat diversity", several authors have used the number of biotopes occurring in study areas (see Fattorini, 2006a; Tognelli \& Kelt, 2004; Hortal et al., 2009). In addition to the number $(N)$ of land cover categories defined above, I used selected synthetic indices of environmental (landscape) heterogeneity. Although Shannon's index is typically used (e.g. Lobo \& Martín-Piera, 2002; Nogués-Bravo \& Martínez-Rica, 2004; Stefanescu et al., 2004; Maes, 2005), studies on community ecology have demonstrated that no single diversity index encompasses all the characteristics of an ideal index (Magurran, 1988; Krebs, 1999). Therefore, I also used the following indices derived from those used in studies on community ecology (Legendre \& Legendre, 1998; Magurran, 1988, 2004; Hayek \& Buzas, 2010) to express richness, dominance, evenness and relative abundance:

- Simpson dominance index: $C=\sum\left(\frac{A_{i}}{A}\right)^{2}$, where $A_{i}$ is the extent of the land cover category $i$, and $A$ is the total surface of the island. $C$ can vary from 0 if all land cover categories have equal extent to 1 if one category dominates the landscape completely.
- Shannon index (entropy): $H=-\sum \frac{A_{i}}{A} \ln \left(\frac{A_{i}}{A}\right) . H$ ranges from 0 , if one land cover category dominates the landscape completely, to arbitrarily high values for landscapes with many categories, each with a small extent.

- Buzas and Gibson evenness: $e^{H} / N$, where $N$ is the number of categories and $H$ is the Shannon index.

- Pielou equitability (evenness): $J=H / \ln N$.

- Margalef richness index: $D_{\mathrm{Mg}}=(N-1) / \ln (A)$.

- Berger-Parker dominance: $d=A_{\max } / A$, where $A_{\max }$ is the extent of the dominant land cover category.

Species richness can be related to environmental variables, such as measures of island area, distances and environmental heterogeneity in different ways. The relationship between number of species and area (species-area relationship, SAR) was here best modelled with the power function $S=C A^{z}$, where $S$ is the number of species, $A$ is an island's area, and $C$ and $z$ are fitted parameters (Martín \& Goldenfeld, 2006; Fattorini, 2006b; Dengler, 2009).

The power function may be fitted as $\ln S=\ln C+\mathrm{z} \ln A$ using ordinary linear regression, or directly as $S=C A^{z}$ with a nonlinear regression. Although the link function is identical, the two models have different distributional assumptions and are not statistically equivalent for least-square regression (see Williams et al., 2009 for details). Because there is no biological or statistical preference for either model (Dengler, 2009), both were used in this study. The untransformed model was applied using a QuasiNewton algorithm with Statistica 6.0 software. As suggested by 
Williams et al. (2009), residuals were examined with ShapiroWilk statistics to determine which distributional assumption was the most appropriate for modelling the dataset. These tests indicated a marginally significant lack-of-fit for the log-transformed model $(W=0.916, P=0.04)$, but not for the power function fitted using non-linear regression $(W=0.970, P=0.65)$. Thus, preference was given to the untransformed model.

The resulting $z$-value $(z \approx 0.25)$ matched values typically found for island systems (Rosenzweig, 1995; Drakare et al., 2006). The SAR is a consistent phenomenon in insular ecosystems, and the best way to consider other sources of variation in species numbers is through the analysis of residuals from species-area regressions (Crowell, 1986; Rosenzweig, 1995; Price, 2004). Thus, residuals from the SAR were correlated with other geographical variables and environmental heterogeneity indices using Spearman correlation tests, which simply assume monotonic relationships without any reference to particular functions

\section{Analysis of variation in species composition}

Variation in species composition between the islands was analysed with CCA using the CANOCO program, version 4.5A (Ter Braak \& Šmilauer, 2002). A Detrended Correspondence Analysis with the option "detrending-by-segments" (Hill \& Gauch, 1980) produced a first axis of $9.239 \mathrm{SD}$, which is more than $2 \mathrm{SD}$ units and hence indicates that CCA is suitable for this data set (Ter Braak \& Prentice, 1988).

Significance of individual environmental parameters (geographical and environmental variables) was tested using a forward selection with 999 Monte Carlo permutations (see Fattorini, 2011 for details). The influence of geographical and landscape variables were tested separately. Both the extent of different landscape categories and their proportions can be important characteristics of the landscape of a given island. Thus, separate CCAs were performed using alternatively the raw and proportional extent of landscape categories.

Inter-island biogeographical similarity

Canonical Correlation Analysis (CANCOR) was used to analyse the influence of geographical and landscape variables on inter-island biogeographical similarity. The original presence/ absence matrix was then subject to a non-metric multidimensional scaling (NMDS) using the Kulczynski 2 coefficient to construct a dissimilarity matrix (for a discussion of the use of this coefficient in biogeographical analyses, see Hausdorf \& Hennig, 2005). This technique is designed to construct a "map" showing the relationships between a number of objects, given only a table of distances or similarity between them, and is often best at capturing patterns in community data when similarity coefficients are used (Legendre \& Legendre, 1998). The goodness of results obtained by NMDS was measured as stress values. On the basis of the increase in stress values when the number of dimensions was decreased (Shi, 1993) the retention of three dimensions was considered to be sufficiently representative. These three dimensions were used as dependent variables in CANCORs. Separate CANCORs were performed for geographical and environmental variables to meet "rule C" of McGarigal et al. (2000). Inter-island faunal similarity was also investigated by cluster analysis using the Kulczynski 2 coefficient as a measure of distance and the UPGMA (Unweighted pair-group method, arithmetic average) amalgamation rule. NMDS and CANCORs were performed using Statistica 6.0 software.

Both CCA and CANCOR investigate the effects of geographical/environmental variables on species composition from complementary points of view and cannot be considered alternative approaches (McGarigal et al., 2000). CCA identifies geographical/environmental gradients which mainly influence species composition of sites, whereas CANCOR correlates dominant gradients in species assemblages with geographical/ environmental gradients. Thus, CCA is particularly useful for investigating the influence of geographical/environmental gradients on beta diversity (second level of abstraction sensu Tuomisto \& Ruokolainen, 2006) whereas CANCOR investigates the importance of geographical/environmental gradients in regulating variation in beta diversity, i.e. "variation in variation in community composition data" - third level of abstraction sensu Tuomisto \& Ruokolainen (2006).

\section{RESULTS}

\section{Species richness}

Area was an important correlate of species richness and the species-area relationship (SAR) was well modelled by a power function $\left(S=11.5 A^{0.23} ; R^{2}=0.84\right)$. When residuals of the SAR were plotted against other geographical variables, no relationship was found (Table 3). Species richness was also tightly correlated with all measures of landscape heterogeneity (Table 3 ). When residuals of the SAR were correlated with landscape heterogeneity indices, significant correlations were found for Pielou equitability and, possibly, for Simpson dominance and Berger-Parker dominance (Table 3). These results suggest that relationships between species richness and landscape heterogeneity were mainly through area. When the stronger effect of area was removed, the influence of landscape heterogeneity was less evident, although there is an indication that richness tends to increase with landscape diversity and equitability and decrease with landscape homogeneity (Table 3 ).

TABLE 3. Values of Spearman correlation coefficients of species richness and residuals from the species-area relationship (SAR) with geographical and landscape parameters. Abbreviations are the same as those in Tables 1 and 2. Residuals from SAR were calculated using the power function. Values in bold are significant at $P<0.05$.

\begin{tabular}{ccc}
\hline & $\begin{array}{c}\text { Correlation coefficients } \\
\text { between number of spe- } \\
\text { cies and environmental } \\
\text { parameters }\end{array}$ & $\begin{array}{c}\text { Correlation coefficients } \\
\text { between residuals from SAR } \\
\text { and environmental parame- } \\
\text { ters }\end{array}$ \\
\hline$A$ & $\mathbf{0 . 8 5 1}$ & 0.082 \\
$D s$ & -0.040 & -0.194 \\
$D a$ & -0.250 & 0.101 \\
$D i$ & $\mathbf{0 . 4 0 9}$ & 0.188 \\
$S D s$ & -0.024 & 0.281 \\
$S D a$ & -0.114 & 0.133 \\
$S D i$ & 0.232 & 0.081 \\
$N$ & $\mathbf{0 . 8 7 3}$ & 0.314 \\
$C$ & $\mathbf{- 0 . 8 4 0}$ & $-\mathbf{0 . 4 0 3}$ \\
$H$ & $\mathbf{0 . 8 3 1}$ & 0.364 \\
$e^{H} / N$ & $\mathbf{- 0 . 6 2 8}$ & -0.090 \\
$J$ & $\mathbf{0 . 7 3 7}$ & $\mathbf{0 . 5 6 9}$ \\
$D_{M g}$ & $\mathbf{0 . 8 2 8}$ & 0.358 \\
$d$ & $\mathbf{- 0 . 8 7 4}$ & $-\mathbf{0 . 5 0 4}$ \\
\hline
\end{tabular}




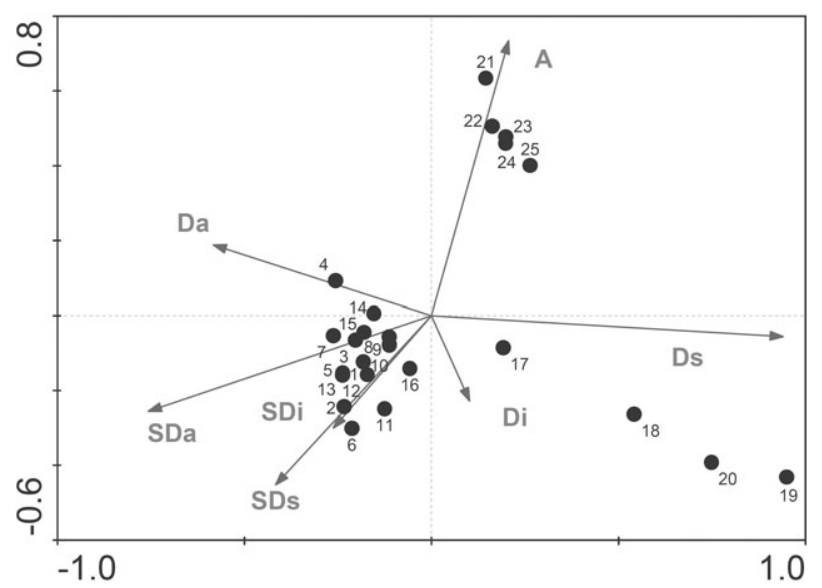

Fig. 2. The results of the CCA of the effect of island characteristics in determining the species composition of tenebrionid beetles on circum-Sicilian islands. The relative importance of individual geographical variables is expressed by the length of the respective vectors. A - Area; Ds - Distance to Sicily; Da Distance to North Africa; Di - Distance to the nearest island; SDs - Sea depth to Sicily; SDa - Sea depth to Africa; SDi Sea depth to the nearest island.

\section{Variation in species composition}

The constrained ordination (CCA) biplot for geographical variables (Fig. 2) resulted in relatively high eigenvalues and cumulative percentage variances, indicative of a well structured data set (Table 4). Moreover, there were strong species-geography correlations with all four axes, which together accounted for about $90 \%$ of the variance explained by the geographical data. Table 4 also shows the correlation coefficients of the geographical variables with four axes of the ordination, the results of the automatic forward selection of the geographical variables, additional fit given by each step and their statistical significance. Distance to Sicily was very strongly related to axis 1 , whereas island area was associated with axis 2 . Axis 1 was also negatively related to maximum water depth between the island in question and Africa (referred to as "depth to Africa"). Distance to Africa and the nearest island were related to axis 3 ; the respective rela- tionships were negative and positive. No variable was distinctly associated with axis 4 . Of these variables, distance to Sicily and distance to Africa have significant conditional effects, whilst water depth to Africa was marginally non-significant. Area and distance to Africa showed similar increases in eigenvalue, whereas distance to Sicily had a substantially higher value of additional fit. Island distance to Sicily was particularly important in determining species composition on Pantelleria and the Pelagie Islands. By contrast, area was particularly important for the Maltese Islands.

Using raw values of land cover categories, the constrained ordination biplot resulted in low eigenvalues and cumulative percentage variances, indicative of a "noisy" data set (Table 5). However, there were strong speciesenvironment correlations with all three axes, which together accounted for $84 \%$ of the variance explained by the environmental data. Use of percentage values of land cover produced even worse results (Table 5). No variable had a significant effect when raw values were used, whilst the percentage of cultivated and grassland areas was the only variable that had a (marginally) significant value $(F$-ratio $=1.55, P=0.05)$ when percentage data were used.

\section{Inter-island biogeographical similarity}

Cluster analysis based on Kulczynski 2 inter-island faunal similarity and UPGMA clustering method produced a dendrogram that reflects the geographical groupings of the islands (Fig. 3). The first basic split separates the Maltese Islands from all other islands. The latter are subdivided into two main clusters: in one are the islands of the Sicilian Channel (Pantelleria and Pelagie) and in the other larger one are the islands closer to Sicily. In this large cluster, two smaller clusters can be identified: one grouping the Egadi Islands with Ustica and another including the Aeolian Islands and islets. Although three dimensions were retained from NMDS and introduced in CANCORs, a biplot of the first two dimensions indicates that these are sufficient to reflect inter-island relationships (Fig. 4). The third dimension was also not significant in CANCORs (see below).

TABLE 4. Results ( $F$-statistics) of CCA for the geographical variables. $\lambda_{\mathrm{a}}$ indicates the increase in eigenvalue (additional fit). $P$ indicates the significance level of the conditional effects based on Monte Carlo tests ( 999 random permutations). Variables are the same as in Table 1.

\begin{tabular}{|c|c|c|c|c|c|c|c|}
\hline \multirow{2}{*}{ Variable } & \multirow{2}{*}{$\lambda_{\mathrm{a}}$} & \multirow{2}{*}{$P$} & \multirow{2}{*}{$F$} & \multicolumn{4}{|c|}{ Weighted correlations } \\
\hline & & & & Axis 1 & Axis 2 & Axis 3 & Axis 4 \\
\hline$D s$ & 0.51 & 0.004 & 2.682 & 0.901 & -0.051 & -0.142 & -0.177 \\
\hline$A$ & 0.35 & 0.083 & 1.900 & 0.211 & 0.687 & 0.221 & -0.336 \\
\hline$D a$ & 0.34 & 0.016 & 1.930 & -0.594 & 0.208 & -0.614 & -0.355 \\
\hline$S D a$ & 0.29 & 0.060 & 1.720 & -0.744 & -0.224 & -0.297 & -0.420 \\
\hline$D i$ & 0.25 & 0.134 & 1.516 & 0.139 & -0.224 & 0.682 & -0.327 \\
\hline$S D i$ & 0.16 & 0.480 & 0.987 & -0.255 & -0.281 & 0.000 & -0.231 \\
\hline$S D s$ & 0.14 & 0.576 & 0.845 & -0.414 & -0.415 & -0.228 & -0.447 \\
\hline \multicolumn{4}{|l|}{ Eigenvalues } & 0.555 & 0.456 & 0.376 & 0.207 \\
\hline \multicolumn{4}{|c|}{ Cumulative $\%$ variance } & 11.3 & 20.6 & 28.3 & 32.6 \\
\hline \multicolumn{4}{|c|}{ Cumulative species-geography relationship } & 27.1 & 49.3 & 67.7 & 77.8 \\
\hline \multicolumn{4}{|c|}{ Species-geography relationship } & 0.964 & 0.961 & 0.963 & 0.899 \\
\hline
\end{tabular}


TABLE 5. Eigenvalues, cumulative explained variance (\%), cumulative species-environment relationship (\%) and speciesenvironment correlations for the first four constrained ordination axes of CCA.

\begin{tabular}{|c|c|c|c|c|}
\hline \multirow{2}{*}{\multicolumn{5}{|c|}{ Land cover (raw values) }} \\
\hline & & & & \\
\hline Eigenvalues & 0.421 & 0.382 & 0.260 & 0.195 \\
\hline Cumulative $\%$ variance & 8.6 & 16.4 & 21.7 & 25.7 \\
\hline $\begin{array}{l}\text { Cumulative species-environment } \\
\text { relationship }\end{array}$ & 25.9 & 49.3 & 5.3 & 77.3 \\
\hline $\begin{array}{c}\text { Species-environment relationship } \\
\text { Land cover ( } \% \text { values) }\end{array}$ & 0.952 & 0.956 & 0.862 & 0.842 \\
\hline Eigenvalues & 0.378 & 0.304 & 0.256 & 0.159 \\
\hline Cumulative \% & 7.7 & 13.9 & 19.1 & 22.4 \\
\hline $\begin{array}{l}\text { Cumulative species-environment } \\
\text { relationship }\end{array}$ & 28.1 .4 & 50.7 & 69.7 & 81.5 \\
\hline Species-environment relationship & 0.870 & 0.304 & 0.256 & 0.159 \\
\hline
\end{tabular}

\section{CANCOR with geographical variables}

With all canonical roots together, that is, without any root removed, the overall CANCOR analysis gave $\chi_{(21)}^{2}=$ 61.30, $P=0.000008$ (canonical $R^{2}=0.87$ ). For the second root, $\chi_{(12)}^{2}=24.27, P=0.02$ (canonical $R^{2}=0.67$ ). Finally, the third root was clearly not significant (canonical $R^{2}=0.18, \chi_{(5)}^{2}=3.73, P=0.82$ ).

Total percentage of variance extracted in the $\mathrm{X}$ set $(53.6 \%)$ was mainly represented by the variance extracted by the first and second roots, while redundancy highlighted the importance of the first root (Table 6). Total redundancy for the $\mathrm{Y}$ set was $57.3 \%$. Looking at the factor structure (structure coefficients or canonical loadings), the first dimension extracted by NMDS was mainly

TABLE 6. Results from CANCOR with all canonical roots analysed. Variables are the same as in Table 1.

\begin{tabular}{lccc}
\hline & \multicolumn{3}{c}{ Factor Structure } \\
\cline { 2 - 4 } & Root 1 & Root 2 & Root 3 \\
\hline Distributional patterns & & & \\
(coordinates from Non-metric & & & \\
Multidimensional Scaling) & & & \\
Dimension 1 & -0.993 & -0.044 & -0.111 \\
Dimension 2 & -0.098 & -0.811 & 0.577 \\
Dimension 3 & -0.066 & 0.584 & 0.809 \\
Variance extracted & 0.333 & 0.333 & 0.333 \\
Redundancy & 0.288 & 0.224 & 0.061 \\
\hline Geographic characteristics & & & \\
$A$ & 0.010 & 0.176 & -0.202 \\
$D s$ & 0.501 & -0.776 & -1.953 \\
Da & -1.748 & -0.695 & 1.888 \\
$D i$ & -0.531 & 0.302 & 0.062 \\
$S D s$ & -0.733 & -0.570 & 2.996 \\
$S D a$ & 3.061 & 0.302 & -4.565 \\
$S D i$ & 0.212 & 0.470 & -0.985 \\
Variance extracted & 0.269 & 0.121 & 0.146 \\
Redundancy & 0.233 & 0.081 & 0.027 \\
Eigenvalues & 0.865 & 0.671 & 0.183 \\
\hline
\end{tabular}

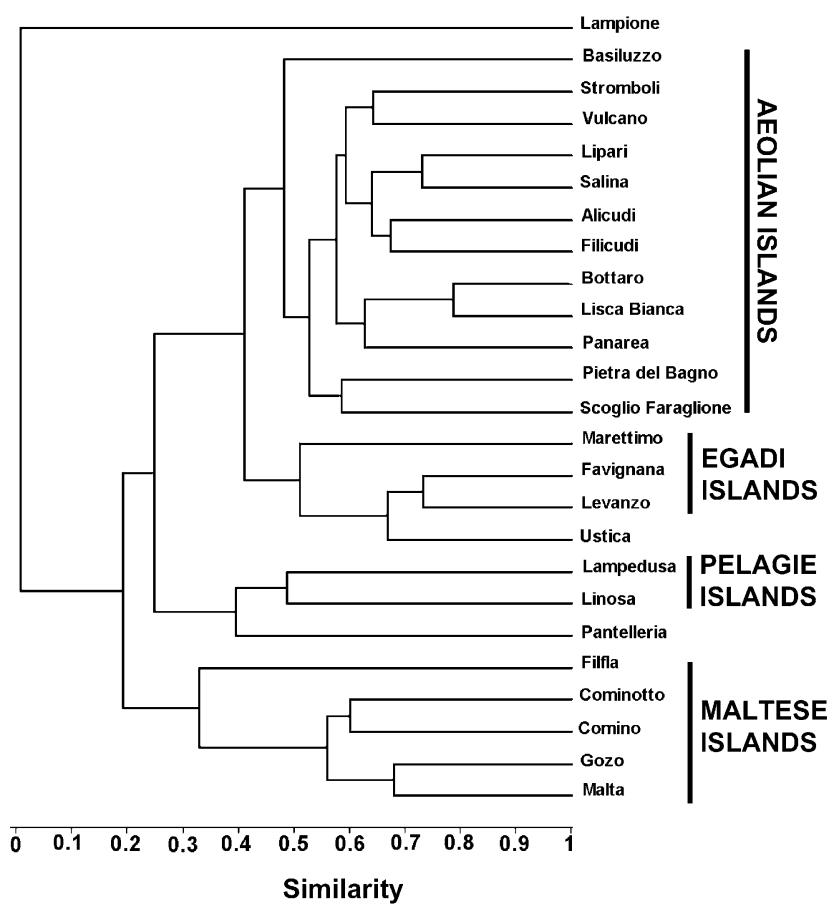

Fig. 3. The relationships between circum-Sicilian islands based on tenebrionid beetles using the Kulczynski 2 index and UPGMA clustering.

influenced by distance to North Africa and sea depth to Africa, while the second one was influenced by distance to Sicily. The third dimension of NMDS was represented by the non-significant root 3 . Thus, current and past isolation from Africa appear to be mainly responsible for the biogeographic relationships among islands represented by the first axis of the NMDS. Current isolation from Sicily is responsible for the biogeographic relationships among islands represented by the second axis of the NMDS (Fig. 4).

CANCOR with environmental variables

With all canonical roots together, CANCOR analysis using raw data of land cover gave $\chi^{2}{ }_{(21)}=19.80, P=0.53$

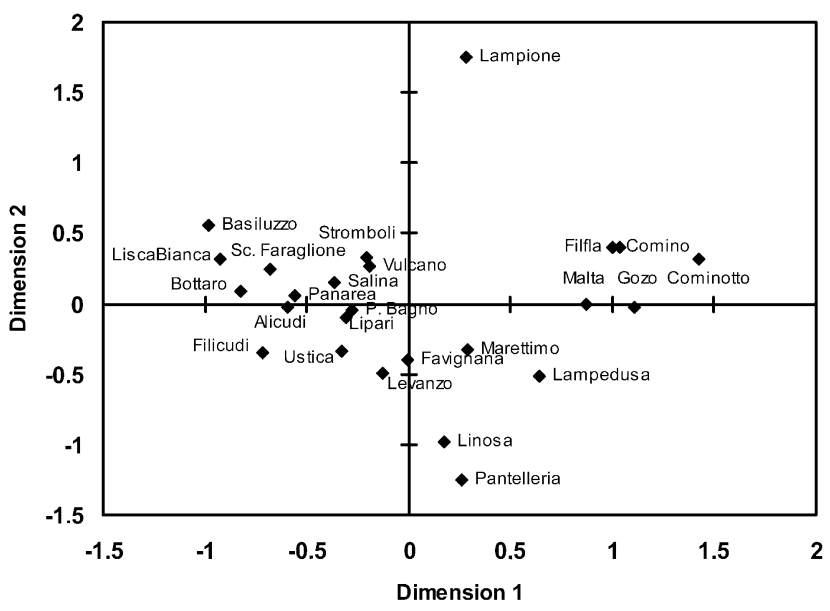

Fig. 4. The relationships between circum-Sicilian islands based on tenebrionid beetles using the Kulczynski 2 index and Non-metric Multidimensional Scaling. 
(canonical $R^{2}=0.56$ ) and percentage of land cover gave $\chi_{(21)}^{2}=20.85, P=0.47$ (canonical $R^{2}=0.52$ ). Thus, in both cases, there was no significant correlation between biogeographical patterns and land cover.

\section{DISCUSSION}

The species-area relationship is the most widespread and best documented pattern in macroecology (cf. Rosenzweig, 1995). For the tenebrionids of the circumSicilian islands, island area accounted for most of the variability in species numbers, as previously observed for other Mediterranean islands (e.g. Fattorini, 2002a, 2009a, $2009 \mathrm{~b}, \mathrm{c})$. Their species richness increased with various measures of environmental diversity and decreased with environmental homogeneity. This accords with the fact that landscape diversity typically increases the diversity of generalist insects (Jonsen \& Fahrig, 1997; Krauss et al., 2003).

Relationship between species richness and environmental diversity in island biogeography is typically investigated within the wider framework of the species-habitat diversity hypothesis (see Hortal et al., 2009). However, this may be incorrect as the term "habitat" is often misused. For example, previous studies using "number of habitats" used, in reality, number of biotopes; see Dennis (2010) for a distinction between habitat and biotope. A recent model by Kadmon \& Allouche (2007) found species richness to follow a uni-modal distribution in relation to increasing biotope numbers ("habitat diversity" according to their use): species diversity initially increases with number of biotopes from a very simple island towards biotope-wise more complex islands, until a maximum species richness is reached, and then it declines because too many biotope types imply that the total areas of individual biotope types are small, reducing the area of suitable biotopes for any given species. In contrast, Hortal et al. (2009) found that species richness on islands usually increases with the number of biotopes and never decreases. Results obtained for the tenebrionids on the circum-Sicilian islands support the findings of Hortal et al. (2009) not only for the number of biotopes but also for various measures of environmental diversity.

In the last few decades, there has been a continuous debate on whether area per se or "habitat" diversity is more important in influencing species richness on islands. Some studies support the idea that the species-area relationship derives from the fact that larger islands have a greater "habitat diversity" (Báldi, 2008; Jonsson et al., 2009), others indicate that there is a strong effect of area per se (Nilsson et al., 1988; Marini et al., 2010) and many report a mixed effect (Ricklefs \& Lovette, 1999; Kallimanis et al., 2008). For the tenebrionids of the circumSicilian islands, correlations between residuals from the species-area relationship and measures of landscape heterogeneity suggest that some of the variation in species richness not explained by area can be attributed to landscape heterogeneity. Thus, both area and landscape diversity may contribute to species richness.
Distances to the nearest island and to the mainland were not identified as of any statistical importance in affecting species numbers. This suggests that, in general, species richness on the circum-Sicilian islands is not regulated by "stepping stone" processes or "mainland-island" dynamics (for an example within the sub-system of the Aeolian Islands, see Fattorini, 2010). This is probably a consequence of two characteristics of the study system. First, the circum-Sicilian islands are a composite assemblage of islands and "stepping stone" processes or "mainland-island" dynamics may be important for some islands (Fattorini, 2010) but not for others. Second, tenebrionids are, in general, sedentary animals and their occurrence on islands is typically better explained by relict models (i.e., by colonization via land-bridge connections followed by local extinction after disconnection) than equilibrial ones (i.e., by current overseas dispersal) (Fattorini, 2002b, 2006a, 2007). Although geographical distances did not exert a clear influence on species richness, they are important in determining species composition. In particular, distance to Sicily exerted an important influence in determining species composition on Pantelleria and the Pelagie Islands, which are among the remotest islands, whereas the distance to Africa was of less importance. These results suggest that colonization of all islands occurred mainly from Sicily and the process depended on the dispersal ability of each species. Lomolino (2000) stressed the importance of differences in the colonization ability of individual species to explain distributional patterns in island systems. The importance of sources and the observation that the impoverishment of island faunas is influenced by species characteristics was recently demonstrated for butterflies on the Tyrrhenian islands (Dapporto \& Dennis, 2008a, 2009). In this respect, species assemblages on highly isolated islands should be strongly affected by isolation, which selects the most "successful" colonizers from the species pool in the source areas.

Island area was particularly important in regulating species assemblages on the Maltese islands. This small archipelago includes the largest islands and is also very isolated. Thus, it is a well defined sub-system and the largest island, Malta, may act as a source of species for its smaller, satellite islands.

The circum-Sicilian islands are biogeographically strongly structured, as revealed by cluster analysis and multidimensional scaling. Both techniques show that faunal similarities among islands reflect their geographical and paleogeographical relationships. CANCORs revealed a strong influence of distance and sea depth to Africa. Thus, although species assemblages on islands are not influenced by relationships with Africa, this is an important factor for inter-island similarity. In particular, position of the Maltese Islands and Lampedusa along the first dimension of multidimensional scaling, related to current and past isolation from Africa, fits with the paleogeographical history of these islands. Relationships of Lampedusa with the African mainland are also testified by the occurrence of African elements, such as 
Allophylax costatipennis costatipennis (Lucas, 1846), Pachychila tazmaltensis Desbrochers des Loges, 1881, Eutagenia aegyptiaca tunisea Normand, 1936, Gonocephalum perplexum (Lucas, 1846) and Microtelus lethierryi Reiche, 1860.

Endemicity levels vary considerably among islands, as a result of their different paleogeographical history. For the Aeolian archipelago, which is very close to Sicily, with a paleogeographical distance strongly reduced during Pleistocene regressions, only one endemic species (Nalassus pastai Aliquò, Leo \& LoCascio, 2006 from Vulcano) is known. Two endemic taxa are known from the Egadi Islands, both from Marettimo, the only island in the Egadi group that remained disconnected from Sicily during Pleistocene regressions. One endemic taxon is known from Ustica and one from Pantelleria. Isolation of these two islands could have favoured some morphological differentiation in their populations, but because of their recent origin, speciation could not occur or be completed until present. The Pelagie Islands are remote and very ancient islands hosting several endemics (four on Lampedusa, two on Lampione, an islet of just $0.03 \mathrm{~km}^{2}$ with four tenebrionid taxa, and one - Machlopsis doderoi Gridelli, 1930 - endemic to Lampedusa and Lampione). No exclusive endemic is known from Linosa, but Stenosis brignonei Koch, 1935 is endemic to Linosa and Lampedusa. The tenebrionid fauna of the Maltese Islands includes nine or ten endemic taxa. Moreover, the Maltese population of Stenosis melitana Reitter, 1894, formerly thought to be endemic but also found relatively recently in southern Sicily, could still represent a distinct form.

\section{CONCLUSIONS}

This study investigated the influence of island geographical and environmental (landscape) features on three main, intercorrelated biogeographical patterns: species richness, species assemblage composition and inter-island faunal similarity of tenebrionid beetles on 25 islands around Sicily. These three patterns were regulated by different factors. Species richness, which does not take into account species identities, was mostly influenced by island area and landscape heterogeneity. When species identities were considered, no substantial effect of landscape was detected. Tenebrionids are detritivorous and most species can exploit a number of different biotopes in several kinds of land cover categories. Thus, most species can probably exploit biotopes across a variety of landcover categories. This low environmental specialization brings about low influence of landscape on species assemblage composition, whereas greater landscape heterogeneity supports larger species numbers.

Current isolation does not show a strong influence on species richness, but has a distinct effect in determining species assortments on the remotest islands. Historical factors, i.e. Pleistocene landbridge connections, are not detectable in species richness relationships with geographical variables or in assemblage gradients, but emerge distinctly from inter-island similarities. Thus, the results presented in this study show that the same geo- graphical or environmental gradient may have very different effects on different aspects of species distributions and multiple approaches are needed for understanding multiple biogeographical patterns.

ACKNOWLEDGEMENTS. I wish to express my gratitude to P. Lo Cascio for providing information used to define land cover categories for small Aeolian islets not covered by the GIS of the Italian Ministry of the Environment and Protection of the Territory and Sea. Thanks are due P. Leo and A. Aliquò for suggestions, and to D. Boukal and two anonymous reviewers for their comments on a previous version of his paper.

\section{REFERENCES}

BÁLDI A. 2008: Habitat heterogeneity overrides the species-area relationship. J. Biogeogr. 35: 675-681.

Ter Braak C.J.F. \& Prentice I.C. 1988: A theory of gradient analysis. Adv. Ecol. Res. 18: 271-317.

Ter Braak C.J.F. \& Smilauer P. 2002: CANOCO Reference Manual and CanoDraw for Windows User's Guide. Software for Canonical Community Ordination (Version 4.5). Microcomputer Power, Ithaca, NY, 500 pp.

CAPUla M. 1994: Genetic variation and differentiation in the lizard, Podarcis wagleriana (Reptilia: Lacertidae). Biol. J. Linn. Soc. 52: 177-196.

Chatzimanolis S., Trichas A., Gioaks S. \& Mylonas M. 2003: Phylogenetic analysis and biogeography of Aegean taxa of the genus Dendarus (Coleoptera: Tenebrionidae). Insect Syst. Evol. 34: 295-312.

Corti C., lo Cascio P., Vanni S., Turrisi G.F. \& Vaccaro A. 1998: Amphibians and reptiles of the circumsicilian islands: new data and some considerations. Boll. Mus. Reg. Sci. Nat. Torino 15: 179-211.

Crowell K.L. 1986: A comparison of relict versus equilibrium models for insular mammals of the Gulf of Maine. Biol. J. Linn. Soc. 28: 37-64.

DAPPorto L. \& Cini A. 2007: Faunal patterns in the Tuscan archipelago butterflies: The dominant influence is recent geography not paleogeography. Eur. J. Entomol. 104: 497-503.

Dapporto L. \& DenNIS R.L.H. 2008a: Species richness, rarity and endemicity of Italian offshore islands: complementary signals from island-focused and species-focused analyses. $J$. Biogeogr. 35: 664-674.

Dapporto L. \& DenNis R.L.H. 2008b: Island size is not the only consideration. Ranking priorities for the conservation of butterflies on Italian offshore islands. J. Insect Conserv. 12: 237-249.

DApporto L. \& Dennis R.L.H. 2009: Conservation biogeography of large Mediterranean islands. Butterfly impoverishment, conservation priorities and inferences for an ecological "island paradigm". Ecography 32: 169-179.

Dapporto L., Wolf H. \& Strumia F. 2007: Recent geography determines the distribution of some flying Hymenoptera in the Tuscan Archipelago. J. Zool. 272: 37-44.

Dengler J. 2009: Which function describes the species-area relationship best? A review and empirical evaluation. J. Biogeogr. 36: 728-744.

Dennis R.L.H., Shreeve T.G., Olivier A. \& Coutsis J.G. 2000: Contemporary geography dominates butterfly diversity gradients within the Aegean archipelago (Lepidoptera: Papilionoidea, Hesperoidea). J. Biogeogr. 27: 1365-1383.

Dennis R.L.H., Dapporto L., Shreeve T.G., John E., Coutsis J.G., Kudrna O., SaArinen K., Ryrholm N. \& Williams W.R. 2008: Butterflies of European islands: the implications of the 
geography and ecology of rarity and endemicity for conservation. J. Insect Conserv. 12: 205-236.

DenNis R.L.H. 2010: A Resource-based Habitat View for Conservation: Butterflies in the British Landscape. WileyBlackwell, Chichester, 406 pp.

Drakare S., Lennon J.J. \& Hillebrand H. 2006: The imprint of the geographical, evolutionary and ecological context on species-area relationships. Ecol. Lett. 9: 215-227.

FATTORINI S. 2002a: Biogeography of the tenebrionid beetles (Coleoptera, Tenebrionidae) on the Aegean Islands (Greece). J. Biogeogr. 29: 49-67.

FATTORINI S. 2002b: Relict versus dynamic models for tenebrionid beetles of Aegean Islands (Greece) (Coleoptera: Tenebrionidae). Belgian J. Zool. 132: 55-64.

FATTORINI S. 2006a: Spatial patterns of diversity in the tenebrionid beetles (Coleoptera, Tenebrionidae) of the Aegean Islands (Greece). Evol. Ecol. Res. 8: 237-263.

FATTORINI S. 2006b: Detecting biodiversity hotspots by speciesarea relationships: a case study of Mediterranean beetles. Conserv. Biol. 20: 1169-1180.

FATTORINI S. 2007: Non-randomness in the species-area relationship: testing the underlying mechanisms. Oikos 116: 678-689.

FATTORINI S. 2008a: A multidimensional characterization of rarity applied to the Aegean tenebrionid beetles (Coleoptera: Tenebrionidae). J. Insect Conserv. 12: 251-263.

FATTORINI S. 2008b: Ecology and conservation of tenebrionid beetles in Mediterranean coastal areas. In Fattorini S. (ed.): Insect Ecology and Conservation. Research Signpost, Trivandrum, pp. 165-297.

FATTORINI S. 2009a: Both recent and Pleistocene geography determines animal distributional patterns in the Tuscan archipelago. J. Zool. 277: 291-301.

FATTORINI S. 2009b: On the general dynamic model of oceanic island biogeography. J. Biogeogr. 36: 1100-1110.

FATTORINI S. 2009c: Faunal patterns in tenebrionids (Coleoptera: Tenebrionidae) on the Tuscan Islands: the dominance of paleogeography over Recent geography. Eur. J. Entomol. 106: $415-423$.

FATTORINI S. 2010: The influence of geographical and ecological factors on island beta diversity patterns. J. Biogeogr. 37: 1061-1070.

FATTORINI S. 2011: Influence of island geography, age and landscape on species composition in different animal groups. $J$. Biogeogr. 38: 1318-1329.

FERRER J. 2008: Contribución al conocimiento de los Asinini iberobaleares. Segunda nota. Las Alphasida (Glabrasida) del grupo Tricostatae Escalera 1922 (Coleoptera, Tenebrionidae, Pimeliinae). Boln. S.E.A. 43: 61-73.

Foufopoulos J. \& Ives A.R. 1999: Reptile extinctions on landbridge islands: life-history attributes and vulnerability to extinction. Am. Nat. 153: 1-25.

Harris D.J., Carretero M.A., Corti C. \& Lo Cascio P. 2009: Genetic affinities of Tarentola mauritanica (Reptilia: Gekkonidae) from Lampedusa and Conigli islet (SW Italy). NorthWest. J. Zool. 5: 197-205.

Hausdorf B. \& Hennig C. 2005: The influence of recent geography, palaeogeography and climate on the composition of the fauna of the central Aegean Islands. Biol. J. Linn. Soc. 84: 785-795.

Hayek L.C. \& Buzas M.A. 2010: Surveying Natural Populations. Quantitative Tools for Assessing Biodiversity. Columbia University Press, New York, 590 pp.

Hill M.O. \& Gauch H.G. 1980: Detrended correspondence analysis, an improved ordination technique. Vegetatio 42: $47-58$.
Hortal J., Triantis K.A., Meiri S., Thébault E. \& SfenthouRAKIS S. 2009: Island species richness increases with habitat diversity. Am. Nat. 174: 205-217.

Istituto IdRografico DELla Marina 1997: Mare Mediterraneo $e$ Mar Nero. Map. Istituto Idrografico della Marina, Genova.

JONSEN I.D. \& FAHRIG L. 1997: Response of generalist and specialist insect herbivores to landscape spatial structure. Landscape Ecol. 12: 185-197.

Jonsson M., Yeates G.W. \& Wardle D.A. 2009: Patterns of invertebrate density and taxonomic richness across gradients of area, isolation, and vegetation diversity in a lake-island system. Ecography 32: 963-972.

Italian Ministry of the Environment and Protection of the Territory and Sea 2009: Portale Cartografico Nazionale. Available at: http://www.pcn.minambiente.it/PCN/ (accessed 2 April 2009).

KADMON R. \& AlLOUCHE O. 2007: Integrating the effects of area, isolation, and habitat heterogeneity on species diversity: a unification of island biogeography and niche theory. Am. Nat. 170: 443-454.

Kallimanis A.S., Mazaris A.D., Tzanopoulos J., Halley J.M., Pantis J.D. \& Sgardelis S.P. 2008: How does habitat diversity affect the species-area relationship? Global Ecol. Biogeogr. 17: 532-538.

Krauss J., StefFan-Dewenter I. \& Tscharntke T. 2003: How does landscape context contribute to effects of habitat fragmentation on diversity and population density of butterflies? J. Biogeogr. 30: 889-900.

Legendre P. \& Legendre L. 1998: Numerical Ecology. 2nd ed. Developments in Environmental Modelling. Elsevier, Amsterdam, $870 \mathrm{pp}$.

Löbl I. \& Smetana A. (eds) 2008: Catalogue of Palaearctic Coleoptera. Vol. 5. Tenebrionoidea. Apollo Books, Stenstrup, $670 \mathrm{pp}$.

Lobo J.M. \& MarTíN-PIERA F. 2002: Searching for a predictive model for species richness of Iberian dung beetle based on spatial and environmental variables. Conserv. Biol. 16: $158-173$.

Lomolino M.V. 2000: A species-based theory of insular zoogeography. Global Ecol. Biogeogr. 9: 39-58.

Maes D., Bauwens D., De Bruyn L., Anselin A., Vermeersch G., Van Landuyt W., De Knijf G. \& Gilbert M. 2005: Species richness coincidence: conservation strategies based on predictive modelling. Biodivers. Conserv. 14: 1345-1364.

MagurRan A.E. 1988: Ecological Diversity and its Measurements. Princeton University, Princeton, 179 pp.

Magurran A. 2004: Measuring Biological Diversity. Blackwell Publishing, Malden, $260 \mathrm{pp}$.

Malta Environment and Planning Authorithy 2009: Mapserver. Available at: http://mapserver.mepa.org.mt (accessed 2 April 2009).

Marini L., Bommarco R., Fontana P. \& Battisti A. 2010: Disentangling effects of habitat diversity and area on orthopteran species with contrasting mobility. Biol. Conserv. 143: 2164-2171.

Martín H.G. \& Goldenfeld N. 2006: On the origin and robustness of power-law species-area relationships in ecology. Proc. Natl Acad. Sci. USA 103: 10310-10315.

Mazzola P., Geraci A. \& Raimondo F.M. 2001: Endemismo e biodiversità floristica nelle isole circumsiciliane. Biogeographia 22: 45-63.

McGarigal K., Cushman S. \& Stafford S. 2000: Multivariate Statistics for Wildlife and Ecology Research. Springer, New York, $283 \mathrm{pp}$. 
Nilsson S.G., Bengtsson J. \& As S. 1988: Habitat diversity or area per se? Species richness of woody plants, carabid beetles and land snails on islands. J. Anim. Ecol. 57: 685-704.

Nogués-Bravo D. \& Martínez-Rica J.P. 2004. Factors controlling the spatial species richness pattern of four groups of terrestrial vertebrates in an area between two different biogeographic regions in northern Spain. J. Biogeogr. 31: 629-640.

PRICE J.P. 2004: Floristic biogeography of the Hawaiian Islands: Influences of area, environment and paleogeography. J. Biogeogr. 31: 487-500.

RickLEFs R.E. \& LovetTe I.J. 1999: The roles of island area per se and habitat diversity in the species-area relationships of four lesser antillean faunal groups. J. Anim. Ecol. 68: $1142-1160$.

Rosenzweig M.L. 1995: Species Diversity in Space and Time. Cambridge University Press, Cambridge, $436 \mathrm{pp}$.

RYDER O.A. 1986: Species conservation and systematics: the dilemma of subspecies. Trends Ecol. Evol. 1: 9-10.

SHI G.R. 1993: Multivariate data analysis in palaeoecology and palaeobiogeography - a review. Palaeogeogr. Palaeoclim. Palaeoecol. 105: 199-234.

CORTI E.F 1973: Il popolamento animale e vegetale delle isole circumsiciliane. Atti del XVIII Congresso della Società Italiana di Biogeografia. Lav. Soc. Ital. Biogeogr. N.S. 3: 911-918.
Statsoft Inc. 2001: STATISTICA (Data Analysis Software System). Version 6. Computer Program Manuals. Tulsa, OK [www.statsoft.com].

Stefanescu C., Herrando S. \& Páramo F. 2004: Butterfly species-richness in the north-west Mediterranean Basin: the role of natural and human-induced factors. J. Biogeogr. 31: 905-915.

Tews J., Brose U., Grimm V., Tielbörger K., Wichmann M.C, Schwager M. \& Jeltsch F. 2004: Animal species diversity driven by habitat heterogeneity/diversity: the importance of keystone structures. J. Biogeogr. 31: 79-92.

The Maltese Islands Multimedia Encyclopedia 2011: The environment during the Pliestocene period. Available at: http://www.shadowservices.com/nature/Maltese/Geomorph/ palaeol.htm (accessed 20 February 2011).

Tognelli M.F. \& Kelt D.A. 2004: Analysis of determinants of mammalian species richness in South America using spatial autoregressive models. Ecography 27: 427-436.

WHITTAKER R.J. 1998: Island Biogeography: Ecology, Evolution, and Conservation. Oxford University Press, Oxford, $285 \mathrm{pp}$.

Whittaker R.J., Triantis K.A. \& Ladle R.J. 2008: A general dynamic theory of oceanic island biogeography. J. Biogeogr. 35: 977-994.

Williams M.R., Lamont B.B. \& Henstridge J.D. 2009: Speciesarea functions revisited. J. Biogeogr. 36: 1994-2004.

Received March 14, 2011; revised and accepted June 27, 2011

APPENDIX 1. Presence (1) / absence (0) of tenebrionid beetles on the circum-Sicilian islands. Island numbers as in Table 1. Nomenclature follows Löbl \& Smetana (2008). Numbers in square brackets refer to the references listed below. * = single island endemic; ** = taxon endemic to an archipelago within the circum-Sicilian islands; ? = uncertain identification.

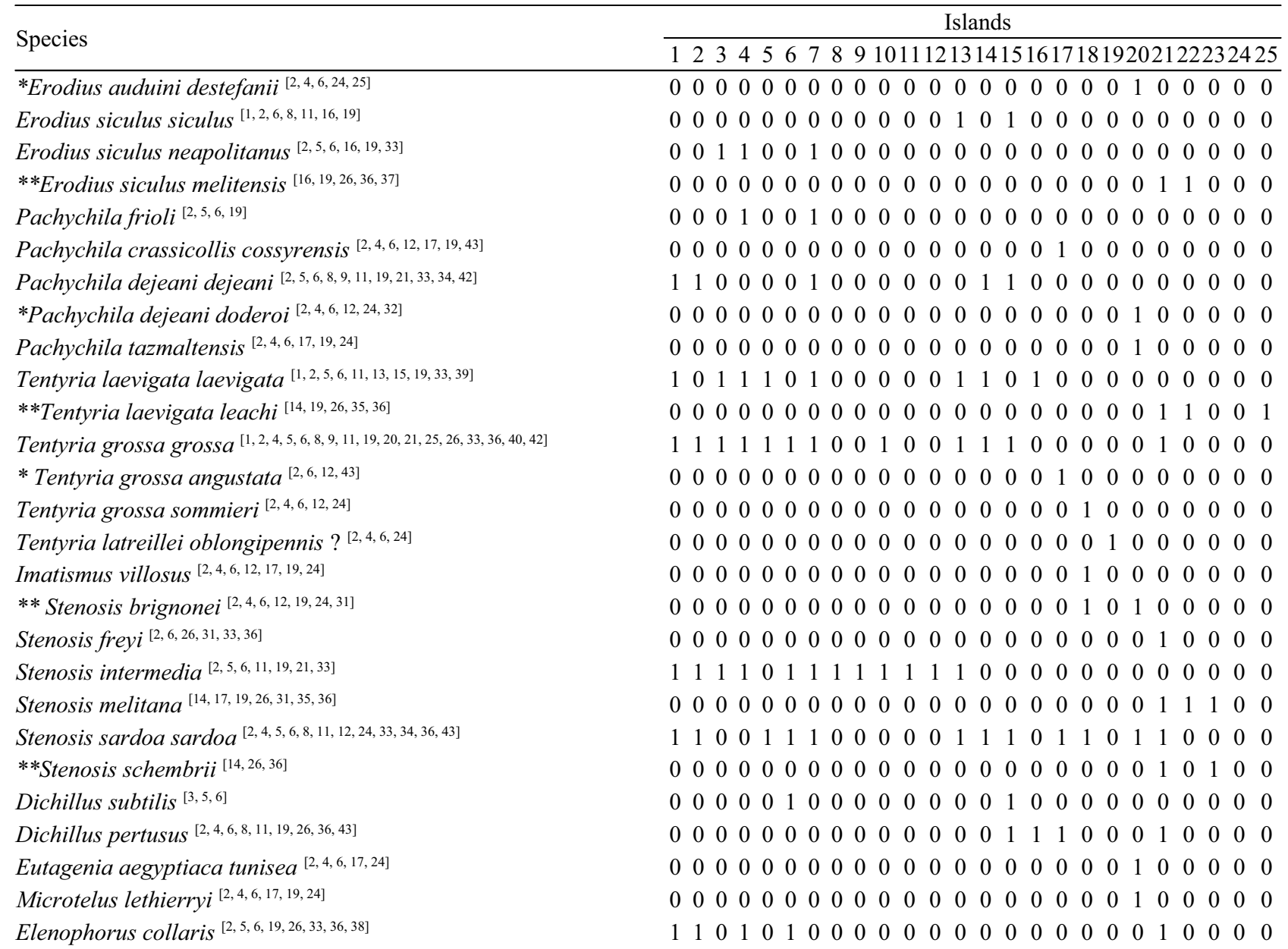




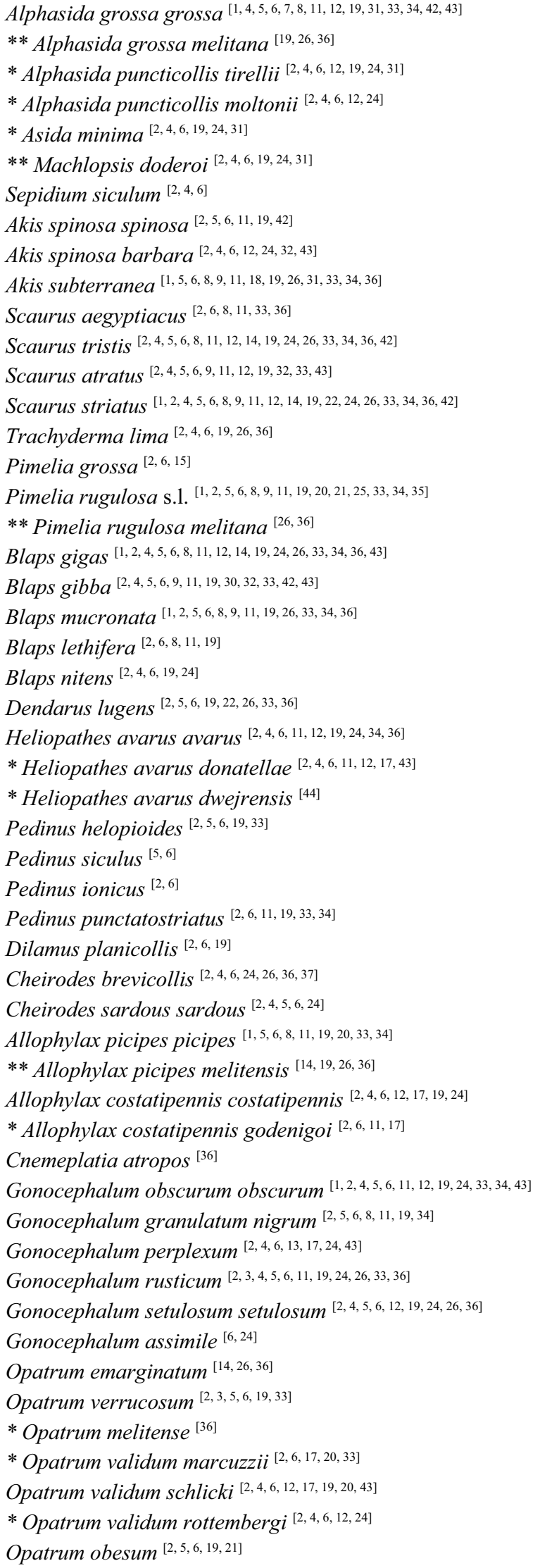

$\begin{array}{lllllllllllllllllllllllll}1 & 1 & 0 & 1 & 0 & 0 & 1 & 0 & 0 & 1 & 1 & 0 & 1 & 1 & 1 & 1 & 1 & 0 & 0 & 0 & 0 & 0 & 0 & 0 & 0\end{array}$ $\begin{array}{lllllllllllllllllllllllll}0 & 0 & 0 & 0 & 0 & 0 & 0 & 0 & 0 & 0 & 0 & 0 & 0 & 0 & 0 & 0 & 0 & 0 & 0 & 0 & 1 & 1 & 1 & 0 & 1\end{array}$ $\begin{array}{lllllllllllllllllllllllll}0 & 0 & 0 & 0 & 0 & 0 & 0 & 0 & 0 & 0 & 0 & 0 & 0 & 0 & 0 & 0 & 0 & 0 & 0 & 1 & 0 & 0 & 0 & 0 & 0\end{array}$ $\begin{array}{lllllllllllllllllllllllll}0 & 0 & 0 & 0 & 0 & 0 & 0 & 0 & 0 & 0 & 0 & 0 & 0 & 0 & 0 & 0 & 0 & 0 & 1 & 0 & 0 & 0 & 0 & 0 & 0\end{array}$ $\begin{array}{lllllllllllllllllllllllll}0 & 0 & 0 & 0 & 0 & 0 & 0 & 0 & 0 & 0 & 0 & 0 & 0 & 0 & 0 & 0 & 0 & 0 & 0 & 1 & 0 & 0 & 0 & 0 & 0\end{array}$ $\begin{array}{lllllllllllllllllllllllll}0 & 0 & 0 & 0 & 0 & 0 & 0 & 0 & 0 & 0 & 0 & 0 & 0 & 0 & 0 & 0 & 0 & 0 & 1 & 1 & 0 & 0 & 0 & 0 & 0\end{array}$ $\begin{array}{lllllllllllllllllllllllll}0 & 0 & 0 & 0 & 0 & 0 & 0 & 0 & 0 & 0 & 0 & 0 & 0 & 0 & 0 & 0 & 1 & 0 & 0 & 0 & 0 & 0 & 0 & 0 & 0\end{array}$ $\begin{array}{lllllllllllllllllllllllll}0 & 0 & 0 & 0 & 0 & 1 & 1 & 0 & 0 & 0 & 0 & 0 & 1 & 1 & 0 & 0 & 0 & 0 & 0 & 0 & 0 & 0 & 0 & 0 & 0\end{array}$ $\begin{array}{lllllllllllllllllllllllll}0 & 0 & 0 & 0 & 0 & 0 & 0 & 0 & 0 & 0 & 0 & 0 & 0 & 0 & 0 & 0 & 1 & 1 & 0 & 1 & 0 & 0 & 0 & 0 & 0\end{array}$ $\begin{array}{lllllllllllllllllllllllll}1 & 0 & 1 & 0 & 0 & 1 & 1 & 0 & 0 & 0 & 0 & 0 & 1 & 1 & 1 & 1 & 0 & 0 & 0 & 0 & 1 & 1 & 0 & 0 & 1\end{array}$ $\begin{array}{lllllllllllllllllllllllll}0 & 0 & 0 & 0 & 0 & 0 & 0 & 0 & 0 & 0 & 0 & 0 & 0 & 0 & 1 & 0 & 0 & 0 & 0 & 0 & 0 & 1 & 0 & 0 & 0\end{array}$ $\begin{array}{lllllllllllllllllllllllll}1 & 1 & 0 & 1 & 0 & 1 & 1 & 0 & 0 & 0 & 0 & 0 & 1 & 1 & 1 & 0 & 0 & 1 & 0 & 1 & 1 & 1 & 0 & 0 & 0\end{array}$

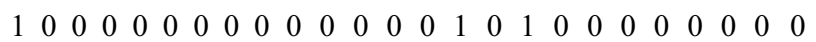
$\begin{array}{lllllllllllllllllllllllll}1 & 1 & 1 & 1 & 1 & 1 & 1 & 0 & 1 & 1 & 0 & 1 & 1 & 1 & 1 & 0 & 0 & 1 & 0 & 1 & 1 & 1 & 1 & 0 & 0\end{array}$ $\begin{array}{lllllllllllllllllllllllll}0 & 0 & 0 & 0 & 0 & 0 & 0 & 0 & 0 & 0 & 0 & 0 & 0 & 0 & 0 & 0 & 1 & 0 & 0 & 0 & 1 & 0 & 0 & 0 & 0\end{array}$ $\begin{array}{lllllllllllllllllllllllll}0 & 0 & 0 & 0 & 0 & 0 & 0 & 0 & 0 & 0 & 0 & 0 & 0 & 0 & 0 & 1 & 0 & 0 & 0 & 0 & 0 & 0 & 0 & 0 & 0\end{array}$ $\begin{array}{lllllllllllllllllllllllll}1 & 1 & 1 & 1 & 1 & 1 & 1 & 0 & 1 & 1 & 1 & 0 & 0 & 0 & 1 & 0 & 0 & 0 & 0 & 0 & 0 & 0 & 0 & 0 & 0\end{array}$ $\begin{array}{lllllllllllllllllllllllll}0 & 0 & 0 & 0 & 0 & 0 & 0 & 0 & 0 & 0 & 0 & 0 & 0 & 0 & 0 & 0 & 0 & 0 & 0 & 0 & 1 & 1 & 0 & 0 & 0\end{array}$ $\begin{array}{lllllllllllllllllllllllll}1 & 1 & 1 & 1 & 1 & 1 & 1 & 0 & 0 & 0 & 1 & 1 & 1 & 1 & 1 & 1 & 1 & 1 & 0 & 1 & 1 & 1 & 1 & 0 & 0\end{array}$ $\begin{array}{lllllllllllllllllllllllll}1 & 1 & 1 & 1 & 0 & 1 & 0 & 0 & 0 & 0 & 0 & 0 & 1 & 1 & 1 & 0 & 1 & 0 & 0 & 0 & 0 & 0 & 0 & 0 & 0\end{array}$ $\begin{array}{lllllllllllllllllllllllll}1 & 0 & 1 & 1 & 1 & 1 & 0 & 0 & 0 & 0 & 0 & 0 & 1 & 1 & 1 & 1 & 0 & 0 & 0 & 0 & 1 & 0 & 0 & 0 & 0\end{array}$ $\begin{array}{lllllllllllllllllllllllll}0 & 0 & 0 & 0 & 0 & 0 & 0 & 0 & 0 & 0 & 0 & 0 & 0 & 1 & 1 & 1 & 0 & 0 & 0 & 0 & 0 & 0 & 0 & 0 & 0\end{array}$ $\begin{array}{lllllllllllllllllllllllll}0 & 0 & 0 & 0 & 0 & 0 & 0 & 0 & 0 & 0 & 0 & 0 & 0 & 0 & 0 & 0 & 0 & 0 & 0 & 1 & 0 & 0 & 0 & 0 & 0\end{array}$ $\begin{array}{lllllllllllllllllllllllll}0 & 0 & 0 & 1 & 0 & 0 & 0 & 0 & 0 & 0 & 0 & 0 & 0 & 0 & 1 & 1 & 0 & 0 & 0 & 0 & 1 & 1 & 0 & 0 & 0\end{array}$ $\begin{array}{lllllllllllllllllllllllll}0 & 0 & 0 & 0 & 0 & 0 & 0 & 0 & 0 & 0 & 0 & 0 & 0 & 0 & 1 & 1 & 0 & 0 & 0 & 1 & 0 & 0 & 0 & 0 & 0\end{array}$ $\begin{array}{lllllllllllllllllllllllll}0 & 0 & 0 & 0 & 0 & 0 & 0 & 0 & 0 & 0 & 0 & 0 & 0 & 0 & 0 & 0 & 1 & 0 & 0 & 0 & 0 & 0 & 0 & 0 & 0\end{array}$ $\begin{array}{lllllllllllllllllllllllll}0 & 0 & 0 & 0 & 0 & 0 & 0 & 0 & 0 & 0 & 0 & 0 & 0 & 0 & 0 & 0 & 0 & 0 & 0 & 0 & 0 & 1 & 0 & 0 & 0\end{array}$ $\begin{array}{lllllllllllllllllllllllll}1 & 1 & 0 & 1 & 1 & 0 & 1 & 0 & 0 & 0 & 0 & 0 & 0 & 0 & 0 & 0 & 0 & 0 & 0 & 0 & 0 & 0 & 0 & 0 & 0\end{array}$ $\begin{array}{lllllllllllllllllllllllll}0 & 0 & 0 & 0 & 1 & 0 & 0 & 0 & 0 & 0 & 0 & 0 & 0 & 0 & 0 & 0 & 0 & 0 & 0 & 0 & 0 & 0 & 0 & 0 & 0\end{array}$ $\begin{array}{lllllllllllllllllllllllll}0 & 0 & 0 & 0 & 0 & 0 & 0 & 0 & 0 & 0 & 0 & 0 & 1 & 0 & 0 & 0 & 0 & 0 & 0 & 0 & 0 & 0 & 0 & 0 & 0\end{array}$ $\begin{array}{lllllllllllllllllllllllll}0 & 0 & 0 & 0 & 0 & 0 & 0 & 0 & 0 & 0 & 0 & 0 & 1 & 0 & 1 & 0 & 0 & 0 & 0 & 0 & 0 & 0 & 0 & 0 & 0\end{array}$ $\begin{array}{lllllllllllllllllllllllll}0 & 0 & 0 & 0 & 0 & 0 & 0 & 0 & 0 & 0 & 0 & 0 & 1 & 0 & 0 & 0 & 0 & 0 & 0 & 0 & 0 & 0 & 0 & 0 & 0\end{array}$ $\begin{array}{lllllllllllllllllllllllll}0 & 0 & 0 & 0 & 0 & 0 & 0 & 0 & 0 & 0 & 0 & 0 & 0 & 0 & 0 & 0 & 0 & 1 & 0 & 0 & 1 & 0 & 0 & 0 & 0\end{array}$ $\begin{array}{lllllllllllllllllllllllll}1 & 1 & 1 & 1 & 0 & 0 & 0 & 0 & 0 & 0 & 0 & 0 & 0 & 0 & 0 & 0 & 0 & 1 & 0 & 0 & 0 & 0 & 0 & 0 & 0\end{array}$ $\begin{array}{lllllllllllllllllllllllll}1 & 1 & 1 & 0 & 1 & 1 & 1 & 1 & 1 & 1 & 0 & 0 & 1 & 1 & 1 & 1 & 0 & 0 & 0 & 0 & 0 & 0 & 0 & 0 & 0\end{array}$ $\begin{array}{llllllllllllllllllllllllll}0 & 0 & 0 & 0 & 0 & 0 & 0 & 0 & 0 & 0 & 0 & 0 & 0 & 0 & 0 & 0 & 0 & 0 & 0 & 0 & 1 & 1 & 1 & 1 & 0\end{array}$ $\begin{array}{lllllllllllllllllllllllll}0 & 0 & 0 & 0 & 0 & 0 & 0 & 0 & 0 & 0 & 0 & 0 & 0 & 0 & 0 & 0 & 0 & 1 & 0 & 1 & 0 & 0 & 0 & 0 & 0\end{array}$ $\begin{array}{lllllllllllllllllllllllll}0 & 0 & 0 & 0 & 0 & 0 & 0 & 0 & 0 & 0 & 0 & 0 & 0 & 0 & 0 & 1 & 0 & 0 & 0 & 0 & 0 & 0 & 0 & 0 & 0\end{array}$ $\begin{array}{lllllllllllllllllllllllll}0 & 0 & 0 & 0 & 0 & 0 & 0 & 0 & 0 & 0 & 0 & 0 & 0 & 0 & 0 & 0 & 0 & 0 & 0 & 0 & 1 & 0 & 0 & 0 & 0\end{array}$ $\begin{array}{lllllllllllllllllllllllll}1 & 0 & 1 & 0 & 1 & 0 & 1 & 0 & 0 & 0 & 0 & 0 & 0 & 1 & 1 & 0 & 1 & 1 & 0 & 1 & 0 & 0 & 0 & 0 & 0\end{array}$ $\begin{array}{lllllllllllllllllllllllll}1 & 1 & 0 & 0 & 0 & 0 & 0 & 0 & 0 & 0 & 0 & 0 & 1 & 0 & 1 & 0 & 0 & 0 & 0 & 0 & 0 & 0 & 0 & 0 & 0\end{array}$ $\begin{array}{lllllllllllllllllllllllll}0 & 0 & 0 & 0 & 0 & 0 & 0 & 0 & 0 & 0 & 0 & 0 & 0 & 0 & 0 & 0 & 1 & 0 & 0 & 1 & 0 & 0 & 0 & 0 & 0\end{array}$ $\begin{array}{lllllllllllllllllllllllll}1 & 1 & 1 & 0 & 0 & 0 & 0 & 0 & 0 & 0 & 0 & 0 & 1 & 1 & 1 & 0 & 1 & 1 & 0 & 1 & 1 & 1 & 0 & 0 & 0\end{array}$

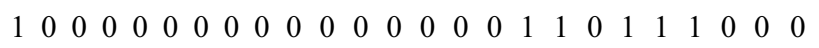
$\begin{array}{lllllllllllllllllllllllll}0 & 0 & 0 & 0 & 0 & 0 & 0 & 0 & 0 & 0 & 0 & 0 & 0 & 0 & 0 & 0 & 0 & 1 & 0 & 0 & 0 & 0 & 0 & 0 & 0\end{array}$ $\begin{array}{lllllllllllllllllllllllll}0 & 0 & 0 & 0 & 0 & 0 & 0 & 0 & 0 & 0 & 0 & 0 & 0 & 0 & 0 & 0 & 0 & 0 & 0 & 0 & 1 & 0 & 0 & 0 & 0\end{array}$ $\begin{array}{lllllllllllllllllllllllll}1 & 1 & 1 & 1 & 1 & 1 & 1 & 1 & 0 & 0 & 0 & 0 & 0 & 0 & 0 & 0 & 0 & 0 & 0 & 0 & 0 & 0 & 0 & 0 & 0\end{array}$ $\begin{array}{lllllllllllllllllllllllll}0 & 0 & 0 & 0 & 0 & 0 & 0 & 0 & 0 & 0 & 0 & 0 & 0 & 0 & 0 & 0 & 0 & 0 & 0 & 0 & 1 & 0 & 0 & 0 & 0\end{array}$ $\begin{array}{lllllllllllllllllllllllll}0 & 0 & 0 & 0 & 0 & 0 & 0 & 0 & 0 & 0 & 0 & 0 & 1 & 0 & 0 & 0 & 0 & 0 & 0 & 0 & 0 & 0 & 0 & 0 & 0\end{array}$ $\begin{array}{lllllllllllllllllllllllll}0 & 0 & 0 & 0 & 0 & 0 & 0 & 0 & 0 & 0 & 0 & 0 & 0 & 0 & 0 & 0 & 1 & 0 & 0 & 0 & 0 & 0 & 0 & 0 & 0\end{array}$ $\begin{array}{lllllllllllllllllllllllll}0 & 0 & 0 & 0 & 0 & 0 & 0 & 0 & 0 & 0 & 0 & 0 & 0 & 0 & 0 & 0 & 0 & 0 & 1 & 0 & 0 & 0 & 0 & 0 & 0\end{array}$ $\begin{array}{lllllllllllllllllllllllll}0 & 1 & 0 & 0 & 0 & 0 & 0 & 0 & 0 & 0 & 0 & 0 & 0 & 0 & 0 & 0 & 0 & 0 & 0 & 0 & 0 & 0 & 0 & 0 & 0\end{array}$ $\begin{array}{llllllllllllllllllllllllll}0 & 0 & 0 & 0 & 0 & 0 & 0 & 0 & 0 & 0 & 0 & 0 & 1 & 1 & 1 & 1 & 1 & 1 & 0 & 0 & 1 & 1 & 0 & 0 & 0\end{array}$ $\begin{array}{lllllllllllllllllllllllll}0 & 1 & 1 & 1 & 0 & 0 & 1 & 0 & 0 & 0 & 0 & 0 & 0 & 0 & 0 & 0 & 0 & 0 & 0 & 1 & 1 & 1 & 1 & 0 & 0\end{array}$ $\begin{array}{lllllllllllllllllllllllll}0 & 0 & 0 & 0 & 0 & 0 & 0 & 0 & 0 & 0 & 0 & 0 & 0 & 0 & 0 & 0 & 0 & 0 & 0 & 0 & 1 & 1 & 0 & 0 & 0\end{array}$ $\begin{array}{lllllllllllllllllllllllll}0 & 1 & 1 & 1 & 0 & 0 & 0 & 0 & 0 & 0 & 0 & 0 & 0 & 0 & 0 & 0 & 0 & 0 & 0 & 1 & 1 & 1 & 1 & 0 & 0\end{array}$ 


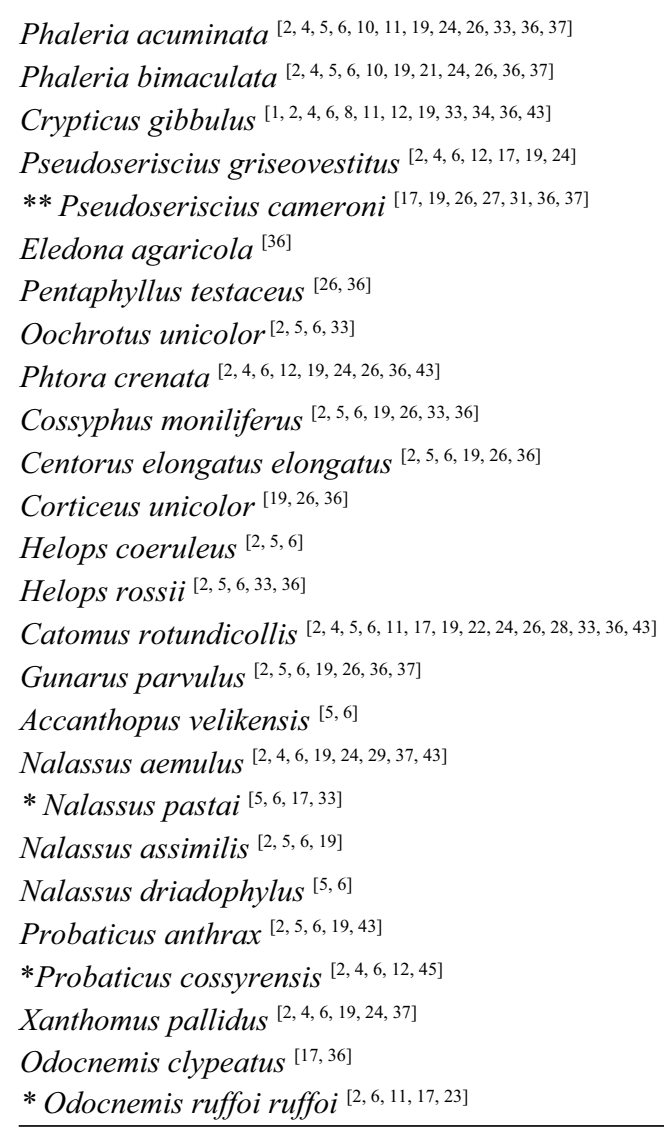

\section{REFERENCES USED IN APPENDIX 1}

${ }^{1}$ Aliquò V. 1971: Brevi note sui Tenebrionidi di Levanzo (Is. Egadi) (Col. Tenebrionidae). Boll. Ass. Romana Entomol. 26: 17-18.

${ }^{2}$ Alıquò V. 1993: Dati nuovi e riassuntivi sui Coleotteri Tenebrionidi delle isole circum-siciliane (Coleoptera: Tenebrionidae). Naturalista Sicil. 17: 111-125.

${ }^{3}$ Aliquò V. 1995a: Nuovi reperti di Tenebrionidae delle isole circumsiciliane. Naturalista Sicil. 19: 131.

${ }^{4}$ Aliquò V. 1995b: Coleoptera Tenebrionidae. Naturalista Sicil. (Suppl.) 19: 543-548.

5 Aliquò V., Leo P. \& Lo Cascio P. 2006: I Tenebrionidi dell'Arcipelago Eoliano: nuovi dati faunistici e zoogeografici con descrizione di una nuova specie di Nalassus Mulsant, 1854 (Coleoptera: Tenebrionidae). Naturalista Sicil. 30: 293-314.

6 Aliquò V. \& Soldati F. 2010: Coleotteri Tenebrionidi di Sicilia. Danaus, Palermo, 176 pp.

7 CAnzoneri S. 1963: Sulla Alphasida grossa Sol., con descrizione di una nuova sottospecie (XII Contributo allo studio dei Tenebrionidi) Boll. Soc. Entomol. Ital. 92: 35-36.

8 Canzoneri S. 1968a: Primi dati sui Tenebrionidae di Favignana (XVI contributo allo studio dei Tenebrionidi). Boll. Mus. Civ. Stor. Nat. Venezia 18: 91-108.

${ }^{9}$ Canzoneri S. 1968b: Alcuni Coleotteri Tenebrionidi delle Isole Eolie (XVII contributo allo studio dei Tenebrionidae). Boll. Ass. Romana Entomol. 23: 49-50.

${ }^{10}$ CAnzoneri S. 1968c: Materiali per una monografia delle Phaleria del sottogenere Phaleria Latr. (XX Contributo alla conoscenza dei Coleoptera Tenebrionidae) Mem. Soc. Entomol. Ital. 47: 117-167. $\begin{array}{lllllllllllllllllllllllll}1 & 0 & 1 & 0 & 0 & 0 & 0 & 0 & 0 & 0 & 0 & 0 & 0 & 0 & 0 & 0 & 0 & 0 & 0 & 1 & 1 & 1 & 0 & 0 & 0\end{array}$ $\begin{array}{llllllllllllllllllllllllll}1 & 1 & 1 & 1 & 0 & 0 & 0 & 0 & 0 & 0 & 0 & 0 & 0 & 0 & 1 & 1 & 0 & 0 & 0 & 1 & 1 & 1 & 1 & 1 & 0\end{array}$ $\begin{array}{lllllllllllllllllllllllll}0 & 0 & 0 & 0 & 0 & 0 & 0 & 0 & 0 & 0 & 0 & 0 & 1 & 1 & 1 & 1 & 1 & 0 & 0 & 0 & 1 & 0 & 0 & 0 & 0\end{array}$ $\begin{array}{lllllllllllllllllllllllll}0 & 0 & 0 & 0 & 0 & 0 & 0 & 0 & 0 & 0 & 0 & 0 & 0 & 0 & 0 & 0 & 0 & 1 & 0 & 0 & 0 & 0 & 0 & 0 & 0\end{array}$ $\begin{array}{lllllllllllllllllllllllll}0 & 0 & 0 & 0 & 0 & 0 & 0 & 0 & 0 & 0 & 0 & 0 & 0 & 0 & 0 & 0 & 0 & 0 & 0 & 0 & 1 & 1 & 0 & 0 & 0\end{array}$ $\begin{array}{lllllllllllllllllllllllll}0 & 0 & 0 & 0 & 0 & 0 & 0 & 0 & 0 & 0 & 0 & 0 & 0 & 0 & 0 & 0 & 0 & 0 & 0 & 0 & 1 & 0 & 0 & 0 & 0\end{array}$ $\begin{array}{lllllllllllllllllllllllll}0 & 0 & 0 & 0 & 0 & 0 & 0 & 0 & 0 & 0 & 0 & 0 & 0 & 0 & 0 & 0 & 0 & 0 & 0 & 0 & 1 & 0 & 0 & 0 & 0\end{array}$

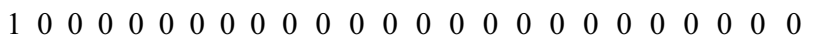
$\begin{array}{lllllllllllllllllllllllll}0 & 0 & 0 & 0 & 0 & 0 & 0 & 0 & 0 & 0 & 0 & 0 & 0 & 0 & 0 & 0 & 1 & 0 & 0 & 1 & 1 & 1 & 0 & 0 & 0\end{array}$ $\begin{array}{lllllllllllllllllllllllll}0 & 1 & 0 & 0 & 0 & 0 & 1 & 0 & 0 & 0 & 0 & 0 & 1 & 0 & 0 & 0 & 0 & 0 & 0 & 0 & 1 & 0 & 0 & 0 & 0\end{array}$

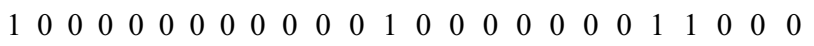
$\begin{array}{lllllllllllllllllllllllll}0 & 0 & 0 & 0 & 0 & 0 & 0 & 0 & 0 & 0 & 0 & 0 & 0 & 0 & 0 & 0 & 0 & 0 & 0 & 0 & 1 & 0 & 0 & 0 & 0\end{array}$

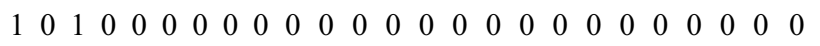

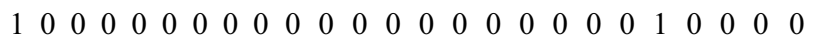
$\begin{array}{lllllllllllllllllllllllll}1 & 0 & 1 & 1 & 1 & 1 & 1 & 0 & 0 & 1 & 0 & 0 & 1 & 0 & 1 & 0 & 1 & 1 & 0 & 1 & 1 & 0 & 0 & 0 & 0\end{array}$ $\begin{array}{lllllllllllllllllllllllll}0 & 0 & 0 & 1 & 0 & 0 & 1 & 0 & 0 & 0 & 0 & 0 & 0 & 0 & 0 & 0 & 0 & 0 & 0 & 0 & 1 & 0 & 1 & 0 & 0\end{array}$ $\begin{array}{lllllllllllllllllllllllll}0 & 0 & 0 & 1 & 0 & 0 & 0 & 0 & 0 & 0 & 0 & 0 & 0 & 0 & 0 & 0 & 0 & 0 & 0 & 0 & 0 & 0 & 0 & 0 & 0\end{array}$ $\begin{array}{lllllllllllllllllllllllll}0 & 0 & 0 & 0 & 0 & 0 & 0 & 0 & 0 & 0 & 0 & 0 & 0 & 0 & 0 & 0 & 1 & 1 & 0 & 0 & 0 & 1 & 0 & 0 & 0\end{array}$ $\begin{array}{lllllllllllllllllllllllll}0 & 0 & 1 & 0 & 0 & 0 & 0 & 0 & 0 & 0 & 0 & 0 & 0 & 0 & 0 & 0 & 0 & 0 & 0 & 0 & 0 & 0 & 0 & 0 & 0\end{array}$ $\begin{array}{lllllllllllllllllllllllll}1 & 1 & 0 & 0 & 1 & 1 & 0 & 0 & 0 & 0 & 0 & 0 & 1 & 0 & 0 & 0 & 0 & 0 & 0 & 0 & 0 & 0 & 0 & 0 & 0\end{array}$ $\begin{array}{lllllllllllllllllllllllll}0 & 0 & 0 & 1 & 0 & 0 & 0 & 0 & 0 & 0 & 0 & 0 & 0 & 0 & 0 & 0 & 0 & 0 & 0 & 0 & 0 & 0 & 0 & 0 & 0\end{array}$ $\begin{array}{lllllllllllllllllllllllll}1 & 1 & 0 & 1 & 1 & 1 & 0 & 0 & 0 & 0 & 0 & 0 & 0 & 0 & 0 & 0 & 0 & 0 & 0 & 0 & 0 & 0 & 0 & 0 & 0\end{array}$ $\begin{array}{lllllllllllllllllllllllll}0 & 0 & 0 & 0 & 0 & 0 & 0 & 0 & 0 & 0 & 0 & 0 & 0 & 0 & 0 & 0 & 1 & 0 & 0 & 0 & 0 & 0 & 0 & 0 & 0\end{array}$ $\begin{array}{lllllllllllllllllllllllll}0 & 0 & 0 & 0 & 0 & 0 & 0 & 0 & 0 & 0 & 0 & 0 & 0 & 0 & 0 & 0 & 0 & 0 & 0 & 1 & 0 & 1 & 0 & 0 & 0\end{array}$ $\begin{array}{lllllllllllllllllllllllll}0 & 0 & 0 & 0 & 0 & 0 & 0 & 0 & 0 & 0 & 0 & 0 & 0 & 0 & 0 & 0 & 0 & 0 & 0 & 0 & 1 & 0 & 0 & 0 & 0\end{array}$ \begin{tabular}{lllllllllllllllllllllllll}
0 & 0 & 0 & 0 & 0 & 0 & 0 & 0 & 0 & 0 & 0 & 0 & 0 & 0 & 0 & 1 & 0 & 0 & 0 & 0 & 0 & 0 & 0 & 0 & 0 \\
\hline
\end{tabular}

${ }^{11}$ Canzoneri S. 1970: I Tenebrionidae delle Isole Egadi (XXII Contributo allo studio dei Tenebrionidi). Mem. Mus. Civ. Stor. Nat. Verona 18: 55-89.

${ }^{12}$ Canzoneri S. 1972: Nuovi dati sui Tenebrionidae di "piccole isole" italiane, con descrizione di Alphasida tirellii moltonii n. ssp. (XXVIII Contributo alla conoscenza dei Tenebrionidi). Atti Soc. Ital. Sci. Nat. Mus. Civ. Stor. Nat. Milano 113: 288-296.

${ }^{13}$ Canzoneri S. 1977: Contributo alla conoscenza dei Tenebrionidi appenninici (XXXI Contributo allo studio dei Tenebrionidi). Boll. Mus. Civ. Stor. Nat. Verona 4: 227-285.

${ }^{14}$ Canzoneri S. 1979: Primi appunti sui Tenebrionidi dell'Arcipelago Maltese (XXXII Contributo allo studio dei Tenebrionidi). Lavori Soc. Ven. Sci. Nat. 4: 20-22.

${ }^{15}$ Castelli V.D. 1986: Segnalazioni faunistiche italiane: 90-91. Tentyria laevigata Stev.; Pimelia grossa Fab. Boll. Soc. Entomol. Ital. 118: 117-118.

${ }^{16}$ Di Stefano G. \& Fattorini S. 2000: Corologia italiana di Erodius siculus ed osservazioni eco-etologiche nel Lazio (Coleoptera, Tenebrionidae). Boll. Ass. Romana Entomol. 55: 27-43.

${ }^{17}$ FAtTORINI S. 2008: Ecology and conservation of tenebrionid beetles in Mediterranean coastal areas. In Fattorini S. (ed.): Insect Ecology and Conservation. Research Signpost, Trivandrum, pp. 165-297.

${ }^{18}$ Fattorini S. \& Leo P. 2000: Darkling beetles from Mediterranean minor islands: new records and biogeographical notes (Coleoptera: Tenebrionidae). Boll. Soc. Entomol. Ital. 132: 205-217.

${ }^{19}$ FoCARILE A. 1969: Sintesi preliminare delle attuali conoscenze sui Coleotteri Tenebrionidi delle piccole isole circumsiciliane (Coleoptera Tenebrionidae). Mem. Soc. Entomol. Ital. 48: 402-416. 
${ }^{20}$ Focarile A. 1970: Ricerche entomologiche nell'Arcipelago delle Eolie e nell'Isola di Ustica (Sicilia). Boll. Soc. Entomol. Ital. 102(9/10): 156-162.

${ }^{21}$ Focarile A. 1972: Ricerche entomologiche nell'Arcipelago delle Eolie e nell'Isola di Ustica (Sicilia). II. La coleotterofauna dello stagno salmastro a Punta Lingua nell'Isola di Salina. Mem. Soc. Entomol. Ital. 51: 19-37.

${ }^{22}$ GardinI G. 1976: Materiali per lo studio dei Tenebrionidi dell'Arcipelago Toscano (Col.: Heteromera) Lavori Soc. Ital. Biogeogr. 5: 637-723.

${ }^{23}$ Gardini G. 1979: Nuovi dati su Tenebrionidi (Col.) dell'Arcipelago Toscano. Boll. Mus. Civ. Stor. Nat. Verona 6: 73-77.

${ }^{24}$ Goggi G. 2004: Indagine faunistica sui Coleotteri delle Isole Pelagie. G. Ital. Entomol. 11: 127-143.

${ }^{25}$ Gridelli E. 1950: Il problema delle specie a diffusione transadriatica con particolare riguardo ai Coleotteri. Memorie Biogeogr. Adriat. 1: 7-299.

${ }^{26}$ Grimm R. 1986: Tenebrionidae vom Maltesischen Archipel (Insecta: Coleoptera). Stuttg. Beitr. Naturk. (A) 392: 1-17.

${ }^{27}$ Leo P. 1982: Gli Pseudoseriscius italiani del gruppo helvolus (Küster) (Coleoptera Tenebrionidae). Natura (Milano) 73: 97-107.

${ }^{28}$ Leo P. 1983: Dati geonemici su alcuni Elopini italiani (Coleoptera, Tenebrionidae). Boll. Ass. Romana Entomol. 36[1981]: $45-48$.

${ }^{29}$ Leo P. 1986: Le popolazioni italiane di Nalassus aemulus (Küster) e descrizione di una nuova razza della Sardegna (Coleoptera: Tenebrionidae: Helopinae). Boll. Mus. Civ. Stor. Nat. Verona 12[1985]: 141-148.

${ }^{30}$ Leo P. \& FatTorini S. 2002: Discovery of natural hybridization in tenebrionid beetles (Coleoptera: Tenebrionidae). Entomol. News 113: 113-120.

${ }^{31}$ Marcuzzi G. 1969: Contributo alla zoogeografia dei Tenebrionidi della Sicilia. Mem. Soc. Entomol. Ital. 48: 499-518.

${ }^{32}$ Marcuzzi G. 1970a: Contributo alla conoscenza dei Coleotteri Tenebrionidi di Sicilia. Boll. Accad. Gioenia Sci. Nat. 10: 406-428.
${ }^{33}$ Marcuzzi G. 1970b: I Tenebrionidi (Col. Heteromera) delle Isole Eolie e di Ustica. Atti. Accad. Gioenia Sc. Nat. 2: 161-184.

${ }^{34}$ Marcuzzi G. 1970c: Contributo alla conoscenza dei Tenebrionidi delle Egadi. Boll. Soc. Entomol. Ital. 102: 87-91.

${ }^{35}$ Marcuzzi G. 1985: I Tenebrionidi (Coleoptera: Heteromera) conservati presso il Museo di Scienze Naturali di Bergamo. Riv. Mus. Sci. Nat. Bergamo 9: 117-125.

${ }^{36}$ Mifsud D. \& Scupola A. 1998: The Tenebrionidae (Coleoptera) of the Maltese Islands (Central Mediterranean). Ann. Mus. Civ. Stor. Nat. “G. Doria” 92: 191-229.

${ }^{37}$ MIFsud D. 1999: Tenebrionids associated with sandy shores in the Maltese Islands (Coleoptera, Tenebrionidae). Central Mediterran. Natur. 3: 23-26.

${ }^{38}$ Mignani R. 1971: Reperti 47. Elenophorus collaris L. (Col. Tenebrionidae). Boll. Ass. Romana Entomol. 24: 30.

${ }^{39}$ Rallo G. 1969a: Reperti 26. Tentyria laevigata Stev. (Col. Tenebrionidae). Boll. Ass. Romana Entomol. 24: 82.

${ }^{40}$ Rallo G. 1969b: Reperti 30. Tentyria grossa grossa Sol. (Col. Tenebrionidae). Boll. Ass. Romana Entomol. 24: 105.

${ }^{41}$ Rallo G. 1969c: Reperti 31. Opatroides punctulatus Brullé (Col. Tenebrionidae). Boll. Ass. Romana Entomol. 24: 105.

42 Rallo G. $1970 \mathrm{Su}$ alcuni Tenebrionidi dell'Isola Levanzo (Col. Heteromera). Boll. Ass. Romana Entomol. 25: 75-76.

${ }^{43}$ Ratti E. 1986: Ricerche faunistiche del Museo civico di Storia naturale di Venezia nell'Isola di Pantelleria. I. Notizie introduttive; Coleoptera Tenebrionidae. Boll. Mus. Civ. Stot. Nat. Venezia 35: 7-41.

${ }^{44}$ Scupola A. \& Mifsud D. 2001: Descrizione di una nuova sottospecie di Heliopathes avarus Mulsant \& Rey, 1854 dell'Isola di Gozo (Arcipelago maltese). Doriana. Suppl. Ann. Mus. Civ. Stor. Nat. "G. Doria” 324: 1-7.

${ }^{45}$ Sparacio I. 2007: Nuovi coleotteri di Sicilia (Coleoptera: Carabidae et Tenebrionidae). Naturalista Sicil. 31: 249-259. 